\title{
Response of ecosystem respiration to experimental warming and clipping in Tibetan alpine meadow at three elevations
}

G. Fu ${ }^{1}$, Y.-J. Zhang ${ }^{1}$, X.-Z. Zhang ${ }^{1}$, P.-L. Shi ${ }^{1}$, Y.-T. Zhou ${ }^{2}$, Y.-L. Li ${ }^{1,3}$, and Z.-X. Shen ${ }^{1}$

${ }^{1}$ Lhasa Plateau Ecosystem Research Station, Key Laboratory of Ecosystem Network Observation and Modeling, Institute of Geographic Sciences and Natural Resources Research, Chinese Academy of Sciences, Beijing 100101, China

${ }^{2}$ Department of Microbiology and Plant Botany, Center for Spatial Analysis, University of Oklahoma, Norman, Oklahoma 73019, USA

${ }^{3}$ University of Chinese Academy of Sciences, Beijing 100049, China

Received: 25 June 2013 - Accepted: 25 July 2013 - Published: 7 August 2013

Correspondence to: Z.-X. Shen (shenzx@igsnrr.ac.cn)

Published by Copernicus Publications on behalf of the European Geosciences Union.

Response of

ecosystem

respiration

G. Fu et al.

Title Page

Abstract Introduction

Conclusions References

Tables Figures

14 $\rightarrow 1$

4

Back Close

\section{Full Screen / Esc}

Printer-friendly Version

Interactive Discussion 


\section{Abstract}

This study aims to understand the response of ecosystem respiration $\left(R_{\text {eco }}\right)$ to warming and clipping in the alpine meadow of Tibet. A field warming experiment using open top chambers was conducted in three alpine meadow sites at elevation $4313 \mathrm{~m}, 4513 \mathrm{~m}$

and $4693 \mathrm{~m}$ on the Tibetan Plateau since July 2008. Clipping was conducted three times a year since 2009. $R_{\text {eco }}$ was measured from June to September in 2010-2012. For most cases, the seasonal variation of $R_{\text {eco }}$ was mainly affected by soil water content rather than soil and air temperature, especially under warmer environment. Experimental warming tended to decrease seasonal average $R_{\text {eco }}$ by $21.6 \%$ and $10.9 \%$ at elevation $4313 \mathrm{~m}$ and $4513 \mathrm{~m}$, respectively, but significantly increased seasonal average $R_{\text {eco }}$ by $11.3 \%$ at elevation $4693 \mathrm{~m}$. The different responses of $R_{\text {eco }}$ to experimental warming could be mainly dependent on temperature and water availability condition. Clipping decreased seasonal average $R_{\text {eco }}$ by $6.9 \%, 36.9 \%$ and $31.6 \%$ at elevation $4313 \mathrm{~m}, 4513 \mathrm{~m}$ and $4693 \mathrm{~m}$. The consistent declines caused by clipping may be mainly attributed to clipping-induced decline in aboveground biomass. Our findings suggested that the response of $R_{\text {eco }}$ to warming differed among the alpine meadow and was regulated by soil water content on the Tibetan Plateau.

\section{Introduction}

Global surface temperature is predicted to increase $1.8-4^{\circ} \mathrm{C}$ by the end of this century and the expected warming magnitude on the Tibetan Plateau is much greater than the global average (IPCC, 2007). The Tibetan Plateau ecosystem is one of the systems most sensitive to global climate change (Miehe et al., 2011; Yu et al., 2012; Sun et al., 2013). Ecosystem respiration $\left(R_{\text {eco }}\right)$ is an important carbon flux in the carbon cycling of terrestrial ecosystems, and is related to primary production and net ecosystem ex-
BGD

10, 13015-13047, 2013

Response of

ecosystem

respiration

G. Fu et al.

Title Page

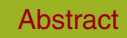

Introduction

Conclusions

References

Tables

Figures

14

$\rightarrow 1$

4

Back

Close

Printer-friendly Version

Interactive Discussion 
have reported the effects of warming on $R_{\text {eco }}$ under controlled warming and clipping conditions, especially along an elevation gradient.

Inconsistent results on the responses of $R_{\text {eco }}$ to climate warming and clipping have been reported for different vegetation types and climate conditions (Welker et al., 2004;

5 Grogan et al., 2001; Wu et al., 2011a). Temperature and water availability have been found to be the two most important abiotic factors controlling $R_{\text {eco }}$ (Shi et al., 2006; Wu et al., 2011b) and their relative contributions can vary with the related environment conditions (Wohlfahrt et al., 2008; Lin et al., 2011). Generally, $R_{\text {eco }}$ increases exponentially with temperature when water availability is not limited (Shi et al., 2006; Lin 10 et al., 2011). Experimental warming-induced soil drying has been observed in various terrestrial ecosystems worldwide (Luo et al., 2001; Li et al., 2011), which may dampen the positive direct effect of experimental warming on $R_{\text {eco }}$ and thereby leads to no significant change in $R_{\text {eco }}$ (Xia et al., 2009; Lin et al., 2011). Climate warming and clipping would lead to changes in nitrogen, microbial biomass, litter, biomass and primary pro15 duction (Klein et al., 2007; Cheng et al., 2010; Fu et al., 2012b), which would in turn influence $R_{\text {eco }}$ (Lin et al., 2011; Yan et al., 2011).

In China, the alpine meadow is concentrated in the western and south-western regions, mostly on the Tibetan Plateau ( $\mathrm{Ni}, 2002)$. The alpine meadow covers about one-third of the Tibetan Plateau and is a major type of pastureland on the Tibetan Plateau (Cao et al., 2004). The alpine meadow stores a large amount of soil organic carbon (SOC) $\left(4.68 \mathrm{Pg}\right.$ ) with SOC density of $9.05 \mathrm{~kg} \mathrm{~m}^{-2}$ at depth of $0-100 \mathrm{~cm}$ (Yang et al., 2008). Understanding the effect of warming on $R_{\text {eco }}$ for the alpine meadow on the Tibetan Plateau is crucial to predict its future status and implement effective restoring and reserving measures under global warming (Yu et al., 2012; Miehe et al., 2008).

25 In this study, we set up an experiment in three alpine meadow sites along an elevation gradient (4313-4693 $\mathrm{m}$ ) on a south-facing slope on the Nyainqentanglha Mountains of the Northern Tibetan Plateau to achieve the following objectives: (1) to compare the response of $R_{\text {eco }}$ to experimental warming and clipping among the three alpine meadows and (2) to investigate correlations among soil and air temperatures and soil

BGD

10, 13015-13047, 2013

Response of

ecosystem

respiration

G. Fu et al.

Title Page

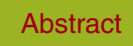

Introduction

Conclusions

Tables

References

Figures

14

4

Back

$>$ I

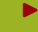

Close

Full Screen / Esc

Printer-friendly Version

Interactive Discussion 
water content on seasonal variation of $R_{\text {eco }}$ during the growing season for the alpine meadow of Tibet.

Temperature sensitivity of respiration declined with increasing temperature (Luo et al., 2001; Zhou et al., 2006) and decreasing elevation (Zimmermann et al., 2009).

5 Additionally, temperature generally decreased with increasing elevation. Therefore, we hypothesized that the response of $R_{\text {eco }}$ to warming could differ among the three alpine meadow sites. Considering aboveground biomass was the substrate of $R_{\text {eco }}$, we hypothesized that clipping could decrease $R_{\text {eco }}$ by removing parts of aboveground biomass. Thirdly, we hypothesized that soil water content could regulate the effects of 10 warming on $R_{\text {eco }}$ because warming may result in soil drying, which in turn suppress $R_{\text {eco }}$.

\section{Materials and methods}

\subsection{Study area}

The study area $\left(30^{\circ} 30^{\prime}-30^{\circ} 32^{\prime} \mathrm{N}, 91^{\circ} 03^{\prime}-91^{\circ} 04^{\prime} \mathrm{E}\right)$ was located at Damxung Grassland $2880.9 \mathrm{~h}$ and the annual mean solar radiation is $7527.6 \mathrm{MJ} \mathrm{m}^{-2}$. The annual mean air temperature is $1.3^{\circ} \mathrm{C}$, ranging from the lowest value $\left(-10.4^{\circ} \mathrm{C}\right)$ in January to the maximum $\left(10.7^{\circ} \mathrm{C}\right)$ in July. Annual mean precipitation is around $476.8 \mathrm{~mm}$, with over $80 \%$ occurring in the period from June to August (Fu et al., 2012a). The annual potential evapotranspiration is about $1725.7 \mathrm{~mm}$. The soil freezing duration is from November to January. The soil texture is sandy loam. The soil layer is $0.5-0.7 \mathrm{~m}$ thick, with organic matter of $0.3-11.2 \%$, total nitrogen of $0.03-0.49 \%$ and $\mathrm{pH}$ of $6.0-6.7$ (Fu et al., 2012c). The typical vegetation type in the study area is Kobresia-dominated alpine meadow (Table 1). Roots are mainly concentrated in the topsoil layer $(0-20 \mathrm{~cm})$.

25 Based on meteorological observations from 1963 to 2012 at Damxung station (4288 $\mathrm{m}$, approximately $4 \mathrm{~km}$ from our study site), annual mean air temperature in-

Response of

ecosystem

respiration

G. Fu et al.

Title Page

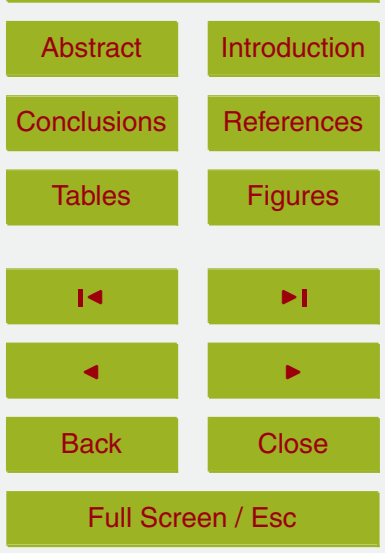

Printer-friendly Version

Interactive Discussion 
creased at a rate of $0.37^{\circ} \mathrm{C} 10 \mathrm{yr}^{-1}$. However, there was no significant change for annual precipitation $(p>0.10)$.

\subsection{Experimental design}

The experiment was set up in three alpine meadow sites located at $4313 \mathrm{~m}, 4513 \mathrm{~m}$ 5 and $4693 \mathrm{~m}$, respectively. The field experiment was based on a complete two factorial design (warming and clipping) with three replicates of each of four treatments: no warming and no clipping (NW + NCL), warming and no clipping $(\mathrm{W}+\mathrm{NCL})$, clipping and no warming $(C L+N W)$, warming plus clipping $(W+C L)$ at each elevation. In this study, open top chambers (OTCs) were used to increase temperature by trap10 ping solar energy (Marion et al., 1997). Six OTCs were randomly set up at each elevation in July 2008. The OTCs remained on the plots year round. The bottom and top diameters and the height of OTCs are $1.45,1.00$ and $0.40 \mathrm{~m}$, respectively (Fu et al., 2012b). There was one unwarmed plot in the vicinity of each OTC. Three of the six OTCs and their paired unwarmed plots were clipped, but the other OTCs and 15 their unwarmed paired plots were not clipped. Clipping was conducted three times a year (generally in June, July and September) for the clipped plots (i.e., CL $+\mathrm{NW}$ and $W+C L$ ) during the growing season since 2009. The aboveground parts of live vegetation were clipped to about $0.01 \mathrm{~m}$ in height for the clipped plots. The clipped aboveground biomass was removed, oven-dried at $65^{\circ} \mathrm{C}$ for $48 \mathrm{~h}$ and weighted. The removed aboveground averaged biomass (mean $\pm \mathrm{SE}$ ) was $34.48 \pm 10.91 \mathrm{~g} \mathrm{~m}^{-2} \mathrm{yr}^{-1}$ and $30.94 \pm 8.20 \mathrm{~g} \mathrm{~m}^{-2} \mathrm{yr}^{-1}, 34.28 \pm 3.84 \mathrm{~g} \mathrm{~m}^{-2} \mathrm{yr}^{-1}$ and $29.69 \pm 1.64 \mathrm{gm}^{-2} \mathrm{yr}^{-1}$ and $37.48 \pm 4.90 \mathrm{~g} \mathrm{~m}^{-2} \mathrm{yr}^{-1}$ and $52.01 \pm 13.32 \mathrm{~g} \mathrm{~m}^{-2} \mathrm{yr}^{-1}$ for $\mathrm{CL}+\mathrm{NW}$ and $\mathrm{W}+\mathrm{CL}$ treatments during the three growing seasons of 2010-2012 at elevation $4313 \mathrm{~m}, 4513 \mathrm{~m}$ and $4693 \mathrm{~m}$, respectively.

25 Soil temperature $\left(T_{\mathrm{s}}\right)$ at a depth of $0.05 \mathrm{~m}$ (S-TMB-M006), soil water content (SWC) at a depth of $0.10 \mathrm{~m}$ (S-SMC-M003), air temperature $\left(T_{\mathrm{a}}\right)$ and relative humidity at a height of $0.15 \mathrm{~m}$ (S-THB-M008) were measured continuously for all treatments at

Response of ecosystem respiration

G. Fu et al.

Title Page

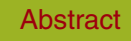

Introduction

Conclusions

Tables

References

Figures

14

$\rightarrow$

4

Back

Close

Full Screen / Esc

Printer-friendly Version

Interactive Discussion 
each elevation during the whole study period. All the channels were connected to data loggers (HOBO weather station, Onset Computer Corporation, USA). OTCs increased seasonal average $T_{\mathrm{s}}$ by $1.13^{\circ} \mathrm{C}, 1.34^{\circ} \mathrm{C}$ and $1.09^{\circ} \mathrm{C}$ and $T_{\mathrm{a}}$ by $1.04^{\circ} \mathrm{C}, 1.41^{\circ} \mathrm{C}$ and $1.01^{\circ} \mathrm{C}$ across the three consecutive growing seasons in 2010-2012 at elevation

$54313 \mathrm{~m}, 4513 \mathrm{~m}$ and $4693 \mathrm{~m}$, respectively $(p<0.05)$. The seasonal average SWC values outside OTCs were $0.16 \mathrm{~m}^{3} \mathrm{~m}^{-3}, 0.20 \mathrm{~m}^{3} \mathrm{~m}^{-3}$ and $0.19 \mathrm{~m}^{3} \mathrm{~m}^{-3}$, whereas those inside OTCs were $0.11 \mathrm{~m}^{3} \mathrm{~m}^{-3}, 0.16 \mathrm{~m}^{3} \mathrm{~m}^{-3}$ and $0.14 \mathrm{~m}^{3} \mathrm{~m}^{-3}$ across the three consecutive growing seasons in 2010-2012 at elevation $4313 \mathrm{~m}, 4513 \mathrm{~m}$ and $4693 \mathrm{~m}$, respectively $(p<0.05)$. The absolute differences of SWC between inside and outside 10 OTCs $\left(-0.05 \mathrm{~m}^{3} \mathrm{~m}^{-3},-0.04 \mathrm{~m}^{3} \mathrm{~m}^{-3}\right.$ and $-0.05 \mathrm{~m}^{3} \mathrm{~m}^{-3}$ at elevation $4313 \mathrm{~m}, 4513 \mathrm{~m}$ and $4693 \mathrm{~m}$, respectively) were close to the observations in an alpine meadow on the Tibetan Plateau (Rui et al., 2011). OTCs-induced increment in $T_{\mathrm{s}}$ and $T_{\mathrm{a}}$ and decrement in SWC were in line with previous studies which showed the warming and drying trends across the Tibetan Plateau (Xie et al., 2010; Zhang et al., 2013). Additionally,

${ }_{15} T_{\mathrm{S}}$ and $T_{a}$ both decreased with increasing elevation during the whole study period $(p<0.05)$. Precipitation increases with increasing altitude along the elevation gradient (Wang et al., 2013).

\subsection{Ecosystem respiration $\left(\boldsymbol{R}_{\mathrm{eco}}\right)$ measurement}

A soil $\mathrm{CO}_{2}$ flux system (LI-8100, LI-COR Biosciences, Lincoln, NE, USA) with an 20 opaque survey chamber of $20 \mathrm{~cm}$ in diameter was used to measure $R_{\text {eco }}$. The measurement time was $90 \mathrm{~s}$ for each sampling. The $R_{\text {eco }}$ was calculated based on $\mathrm{CO}_{2}$ concentration in the opaque survey chamber during the measurement and this process was auto-completed by the LI-8100. One polyvinyl chloride (PVC) collar (20 cm in diameter and $5 \mathrm{~cm}$ in height) was inserted about $2 \sim 3 \mathrm{~cm}$ into the soil for each plot in 2515 May 2010. Insertion of PVC collars into the soil can disturb soil and plant and then affect $R_{\text {eco }}$ measurement. In order to reduce or even eliminate this effect, we started to measure $R_{\text {eco }}$ on 6 June 2010 . The opaque survey chamber was manually mounted on PVC collar in each plot for $R_{\text {eco. }}$. The internal height of the opaque survey chamber is

Response of ecosystem respiration

G. Fu et al.

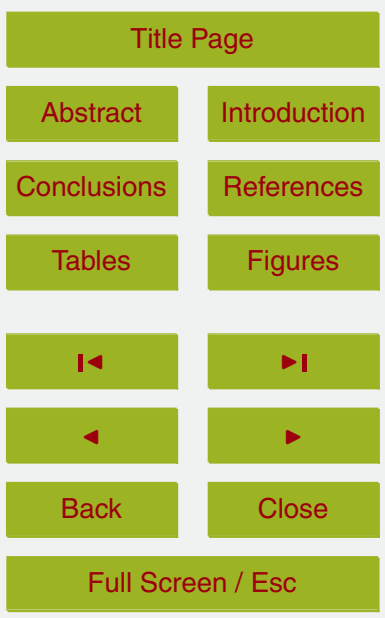

Printer-friendly Version

Interactive Discussion 
approximately $25 \mathrm{~cm}$, thus the opaque survey chamber is high enough to enclose all the plants within it. $R_{\text {eco }}$ was measured during the growing season (from June to September). Diurnal cycles of $R_{\text {eco }}$ measurements were generated from 08:00 to 20:00 (Beijing Standard Time, BST) with a $2 \mathrm{~h}$ interval at each elevation in 2010-2012 (Fig. 1).

\section{$5 \quad 2.4$ Soil sampling and analysis}

Soil samples $(0-20 \mathrm{~cm}$ depth) were collected (with a probe of $5.0 \mathrm{~cm}$ diameter) along the elevation gradient on 11 August 2012. For each of the three replicates, two soil subsamples were randomly sampled and composited into one soil sample at each plot. The soil samples were immediately stored in an icebox and then transferred to laboratory.

10 Each composited soil sample was passed through a sieve (1 $\mathrm{mm}$ diameter) and any visible roots were picked out from the sieved soil. Then subsamples of the sieved soil were used to measure microbial biomass carbon (MBC) and dissolved organic carbon (DOC). Subsamples of the sieved soil were air-dried for the measurement of SOC. All the visible roots in the soil samples were washed, oven-dried at $65^{\circ} \mathrm{C}$ for $48 \mathrm{~h}$ and then weighted. The oven-dried roots were belowground biomass (BGB).

MBC was determined using the chloroform fumigation-extraction method (Vance et al., 1987). Briefly, the fumigated and unfumigated soil samples $(20 \mathrm{~g})$ were both extracted using $80 \mathrm{~mL} 0.5 \mathrm{M} \mathrm{K}_{2} \mathrm{SO}_{4}$. Then $\mathrm{K}_{2} \mathrm{SO}_{4}$ extracts were filtered through $0.45 \mu \mathrm{m}$ filter membrane. The extractable organic carbon in the $\mathrm{K}_{2} \mathrm{SO}_{4}$ extracts was analyzed on a Liqui TOC II elementar analyzer (Elementar Liqui TOC, Elementar Co., Hanau, Germany). The extractable carbon in the $\mathrm{K}_{2} \mathrm{SO}_{4}$ extracts was converted to $\mathrm{MBC}$ using the conversion factor of 0.45 (Fu et al., 2012b).

DOC was determined using the method of Jones and Willett (2006). Briefly, $20 \mathrm{~g}$ fresh soil samples were extracted using $100 \mathrm{~mL}$ distilled water and filtered through

$0.45 \mu \mathrm{m}$ filter membrane. The extractable organic carbon in the distilled water extracts was also analyzed on a Liqui TOC II elementar analyzer (Elementar Liqui TOC, Elementar Co., Hanau, Germany). SOC was determined using the potassium dichromate method (Walkley and Black, 1934).

BGD

10, 13015-13047, 2013

Response of

ecosystem

respiration

G. Fu et al.

Title Page

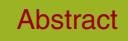

Introduction

Conclusions

Tables

References

Figures

14

$\rightarrow 1$

4

Back

Close

Full Screen / Esc

Printer-friendly Version

Interactive Discussion

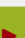

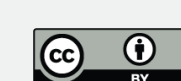




\subsection{Aboveground present biomass}

A non-destructive approach was used to estimate aboveground present biomass (APB, g D.W. $\mathrm{m}^{-2}$ ) (Klein et al., 2007). Canopy coverage (CC, \%) and height $(\mathrm{CH}, \mathrm{cm})$ in a $50 \mathrm{~cm} \times 50 \mathrm{~cm}$ subplot in the center of each plot were measured in August of 2010, 2011 5 and 2012 when maximum APB occurred. Maximum APB during the growing season can be treated as aboveground net primary production (ANPP) in the unclipped plots (Klein et al., 2007). Within each plot, the $50 \mathrm{~cm} \times 50 \mathrm{~cm}$ subplot was divided into $10 \mathrm{~cm} \times$ $10 \mathrm{~cm}$ sub-units. The same measurement was also conducted outside the treatment plots and then the aboveground plant parts were harvested, dried and weighed. A 10 regression equation ( $\mathrm{APB}=-11.49+1.21 \mathrm{CC}+3.75 \mathrm{CH}, R^{2}=0.73, p<0.001, n=90$ ) between $\mathrm{APB}$ and $\mathrm{CC}$ and $\mathrm{CH}$ was developed using the data collected from outside the treatment plots across the three alpine meadow sites along the elevation gradient.

\subsection{Statistical analysis}

Three-way analysis of variance (ANOVA) was used to assess the main and interac15 tive effects of experimental warming, clipping and elevation on SOC, DOC, MBC and BGB. Repeated-measures ANOVA was performed to test effects of year, experimental warming and clipping on APB for each elevation. Repeated-measures ANOVA with elevation, experimental warming and clipping as the between-subject factors and with year as the within-subject factor for growing-season average $R_{\text {eco }}$ was conducted (Ta20 ble 2). Repeated-measures ANOVA was used to estimate the main and interactive effects of measuring date, experimental warming and clipping on diurnal average $R_{\text {eco }}$ in 2010, 2011 and 2012, respectively for each elevation (Table 3). For each treatment, a stepwise multiple regression analysis was applied between diurnal average $R_{\text {eco }}$ and $T_{\mathrm{s}}, T_{\mathrm{a}}$ and SWC (Table 4), before which natural logarithm transformations were made 25 for $R_{\text {eco }}$ and SWC. The temperature sensitivity of $R_{\text {eco }}$ was assessed by relating $R_{\text {eco }}$ to $T_{\mathrm{s}}$ or $T_{\mathrm{a}}$ as follows for a specific treatment using all measuring data.

$R_{\mathrm{eco}}=a e^{b T}$
BGD

10, 13015-13047, 2013

Response of

ecosystem

respiration

G. Fu et al.

Title Page

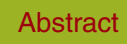

Introduction

Conclusions References

Tables Figures

14 $\rightarrow$ I

4

Back

Close

Full Screen / Esc

Printer-friendly Version

Interactive Discussion 
where $T$ is $T_{\mathrm{s}}$ or $T_{\mathrm{a}}, a$ is the intercept of $R_{\text {eco }}$ when temperature is zero, and $b$ reflects the temperature sensitivity of $R_{\text {eco }}$. The $b$ values were used to calculate the respiration quotient $\left(Q_{10}\right)$, which could reflect the change of $R_{\text {eco }}$ with a $10^{\circ} \mathrm{C}$ increase in $T_{\mathrm{s}}$ or $T_{\mathrm{a}}$.

$Q_{10}=e^{10 b}$

$5 \quad T$ test was used to assess the significance of main and interactive effects of experimental warming and clipping on regression coefficient $b$ (Zhou et al., 2006).

All the statistical tests were performed using the SPSS software (version 16.0; SPSS Inc., Chicago, IL).

\section{Results}

\subsection{SOC, MBC, DOC and BGB}

SOC increased significantly with increasing elevation $\left(F_{2,24}=175.37, p<0.001\right)$. Although MBC, DOC and BGB at elevation $4693 \mathrm{~m}$ was significantly higher compared to elevation $4513 \mathrm{~m}$ and $4313 \mathrm{~m}$, there were no significant differences between elevation $4313 \mathrm{~m}$ and $4513 \mathrm{~m}$. Additionally, no other significant main and interactive effects on $\mathrm{SOC}, \mathrm{MBC}, \mathrm{DOC}$ and BGB were found.

No significant differences of SOC, MBC, DOC and BGB among NW + NCL, W + NCL, $\mathrm{CL}+\mathrm{NW}$ and $\mathrm{W}+\mathrm{CL}$ treatments were found (Fig. 2).

\subsection{Aboveground present biomass}

The responses of APB to experimental warming and clipping varied with year and elevation (Fig. 3). Averaged for the three years, experimental warming significantly decreased APB by $30.5 \%$ at elevation $4313 \mathrm{~m}$, but had little effects on APB at elevation $4513 \mathrm{~m}$ and $4693 \mathrm{~m}$. Clipping consistently reduced APB by $50.0 \%, 48.0 \%$ and $19.0 \%$ at elevation $4313 \mathrm{~m}, 4513 \mathrm{~m}$ and $4693 \mathrm{~m}$ across the three years, respectively $(p<0.05)$.

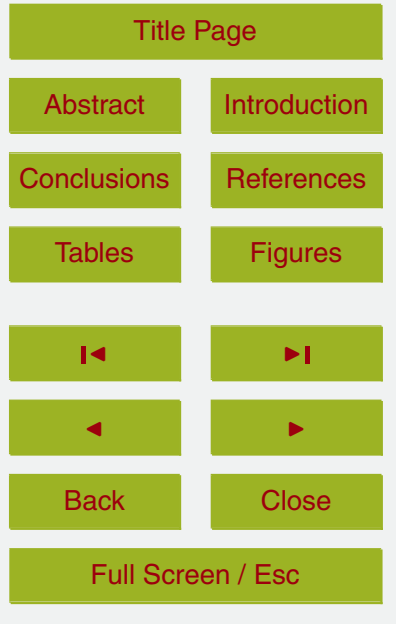

Printer-friendly Version

Interactive Discussion

Title Page

ntroduction

Conclusions

Tables Figures
Response of

ecosystem

respiration

G. Fu et al.

10, 13015-13047, 2013

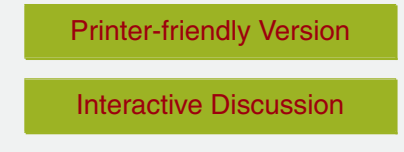


No significant difference of APB between elevation $4313 \mathrm{~m}$ and $4513 \mathrm{~m}$ was found, although they were both significantly lower than that of elevation $4693 \mathrm{~m}$, irrespective of experimental warming, clipping and year effects.

\subsection{Ecosystem respiration}

5 The responses of growing-season average $R_{\text {eco }}$ to experimental warming and clipping varied with elevation and year (Tables 2 and 3 ). Regardless of clipping effect, experimental warming significantly decreased growing-season average $R_{\text {eco }}$ in 2010 by $36.5 \%$ and $22.8 \%$ at elevation $4313 \mathrm{~m}$ and $4513 \mathrm{~m}$, respectively, while the decreases caused by experimental warming in 2011 (by $18.4 \%$ for elevation $4313 \mathrm{~m}$ and by $5.69 \%$ for elevation $4513 \mathrm{~m}$ ) and 2012 (by $10.1 \%$ for elevation $4313 \mathrm{~m}$ and by $5.68 \%$ for elevation $4513 \mathrm{~m}$ ) were not statistically significant. In contrast, experimental warming significantly increased growing-season average $R_{\text {eco }}$ of elevation $4693 \mathrm{~m}$ by $12.2 \%$ and $16.1 \%$ in 2011 and 2012, respectively, whereas the increment (by 5.2\%) in 2010 was not statistically significant. On average, experimental warming significantly increased average $R_{\text {eco }}$ at elevation $4313 \mathrm{~m}$ and $4513 \mathrm{~m}$ across the three consecutive growing seasons in 2010-2012.

For the three growing season averages, clipping significantly reduced seasonal average $R_{\text {eco }}$ by $36.9 \%$ and $31.6 \%$ at elevation $4513 \mathrm{~m}$ and $4693 \mathrm{~m}$, respectively, while 20 had little effect on seasonal average $R_{\text {eco }}$ at elevation $4313 \mathrm{~m}$. In detail, growing-season average $R_{\text {eco }}$ at elevation $4513 \mathrm{~m}$ and $4693 \mathrm{~m}$ was significantly reduced by $36.5 \%$ and $24.1 \%, 37.5 \%$ and $32.1 \%$ and $36.6 \%$ and $37.2 \%$ in 2010, 2011 and 2012, respectively. Clipping tended to decrease growing-season average $R_{\text {eco }}$ by $2.3 \%, 5.6 \%$ and $12.4 \%$ in 2010, 2011 and 2012 at elevation $4313 \mathrm{~m}$, respectively, although these de-

clines were not statistically significant.

The responses of diurnal average $R_{\text {eco }}$ within one-growing-season to experimental warming and clipping varied with measuring date (Fig. 1, Table 3). Experimental warming significantly decreased diurnal average $R_{\text {eco }}$ on 8,9 and 2 out of the 22 measuring 13024
BGD

10, 13015-13047, 2013

Response of

ecosystem

respiration

G. Fu et al.

Title Page

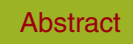

Introduction

Conclusions

Tables

References

Figures

14

$\rightarrow 1$

4

Back

Close

Full Screen / Esc

Printer-friendly Version

Interactive Discussion 
dates at elevation $4313 \mathrm{~m}, 4513 \mathrm{~m}$ and $4693 \mathrm{~m}$, respectively. In contrast, experimental warming significantly increased diurnal average $R_{\text {eco }}$ on 8 out of the 22 measuring dates at elevation $4693 \mathrm{~m}$. Clipping significantly reduced diurnal average $R_{\text {eco }}$ on all the 22 measuring dates at elevation $4513 \mathrm{~m}$ and $4693 \mathrm{~m}$, respectively, but the response 5 magnitudes differed.

No significant difference of $R_{\text {eco }}$ between elevation $4313 \mathrm{~m}$ and $4513 \mathrm{~m}$ was found, although they were both significantly lower than that of elevation $4693 \mathrm{~m}$, irrespective of experimental warming, clipping and year effects.

\subsection{Temperature sensitivity}

10 The $Q_{10}$ values based on $T_{\mathrm{s}}$ in $\mathrm{NW}+\mathrm{NCL}, \mathrm{W}+\mathrm{NCL}, \mathrm{CL}+\mathrm{NW}$ and $\mathrm{W}+\mathrm{CL}$ treatments were $1.32,1.39,1.51$ and 1.38 at elevation $4313 \mathrm{~m}, 1.39,1.21,1.68$ and 1.26 at elevation $4513 \mathrm{~m}, 2.41,1.67,1.99$ and 1.75 at elevation $4693 \mathrm{~m}$, respectively. In contrast, the $Q_{10}$ values based on $T_{a}$ in NW $+N C L, W+N C L, C L+N W$ and $W+C L$ treatments were $1.57,1.45,1.68$ and 1.46 at elevation $4313 \mathrm{~m}, 1.55,1.23,1.80$ and 1.36 at elevation $4513 \mathrm{~m}$ and $2.27,1.72,2.16$ and 1.63 at elevation $4693 \mathrm{~m}$, respectively.

One-way ANOVA showed that elevation had significant effect on the regression coefficient $b$ for the NW $+\mathrm{NCL}$ treatment $\left(F=6.18, p<0.05\right.$ based on $T_{\mathrm{a}} ; F=12.42$, $p<0.05$ based on $T_{\mathrm{s}}$ ). In detail, the regression coefficients $b$ at elevation $4693 \mathrm{~m}$ was significant larger than that at elevation $4513 \mathrm{~m}$ and $4313 \mathrm{~m}$, while there was no significant difference between elevation $4513 \mathrm{~m}$ and $4313 \mathrm{~m}$. In other words, the $Q_{10}$ at elevation $4693 \mathrm{~m}$ was higher in comparison with elevation $4513 \mathrm{~m}$ and $4313 \mathrm{~m}$.

The main effect of experimental warming on the coefficient $b$ was statistical significant for elevation $4513 \mathrm{~m}\left(t=-2.91, p<0.05\right.$ based on $T_{\mathrm{a}} ; t=-2.37, p<0.05$ based on $\left.T_{\mathrm{s}}\right)$ and $4693 \mathrm{~m}\left(t=-3.61, p<0.05\right.$ based on $T_{\mathrm{a}} ; t=-2.94, p<0.05$ based on $\left.T_{\mathrm{s}}\right)$, 25 but not $4313 \mathrm{~m}\left(t=-1.33, p>0.05\right.$ based on $T_{\mathrm{a}} ; t=-0.21, p>0.05$ based on $\left.T_{\mathrm{s}}\right)$. The main effect of clipping and its interaction with experimental warming had little effects on the coefficient $b$.
BGD

10, 13015-13047, 2013

Response of

ecosystem

respiration

G. Fu et al.

Title Page

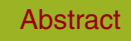

Introduction

Conclusions

References

Tables

Figures

14

- I

4

Back

Close

Full Screen / Esc

Printer-friendly Version

Interactive Discussion 


\subsection{Relationships between $R_{\text {eco }}$ and $T_{\mathrm{s}}$, SWC, $T_{\mathrm{a}}$, APB, ANPP, SOC, DOC, MBC, BGB}

With the exception of SWC, $T_{\mathrm{s}}$ and $T_{\mathrm{a}}$ were excluded in the multiple regression analyses for NW + NCL, W + NCL, CL + NW and W + CL treatments at elevation $4313 \mathrm{~m}$,

$5 \mathrm{~W}+\mathrm{NCL}$ and $\mathrm{W}+\mathrm{CL}$ treatments at elevation $4513 \mathrm{~m}$ and $\mathrm{W}+\mathrm{CL}$ treatment at elevation $4693 \mathrm{~m}$ (Table 4). SWC explained more seasonal variation of $R_{\text {eco }}$ in the multiple regression equations except the NW + NCL treatment at elevation $4693 \mathrm{~m}$ (Table 4).

Growing-season average $R_{\text {eco }}$ increased with increasing SOC, DOC, MBC, BGB and ANPP along warming and clipping treatments and elevation (Figs. 4 and 5).

\section{Discussion}

\subsection{Warming effect}

Previous studies showed that warming exerted no influence on seasonal average $R_{\text {eco }}$ in dry subarctic heath (Illeris et al., 2004) and temperate and alpine grasslands (Xia et al., 2009; Lin et al., 2011), while enhanced $R_{\text {eco }}$ throughout growing season in Alaska and Arctic Tundra ecosystems (Welker et al., 1999; Hobbie and Chapin, 1998), and increased $R_{\text {eco }}$ in alpine tundra and meadow early in growing season (Welker et al., 1999; Zhuang et al., 2010). Similarly, we also found variable warming effects on seasonal average $R_{\text {eco }}$ among the three elevations (Tables 2 and 3), which was in line with our hypothesis. Therefore, warming had ecosystem-specific effects on $R_{\text {eco }}$ (De Boeck et al., 2007; Oberbauer et al., 2007; Welker et al., 2004; Wu et al., 2011b).

The $Q_{10}$ values of $R_{\text {eco }}$ were larger than 1.0 at the three elevations, which implied warming should increase $R_{\text {eco }}$. However, experimental warming could not increase but even tend to decrease $R_{\text {eco }}$ for the two lower elevations. Therefore, inconsistent with our hypothesis, temperature sensitivity of $R_{\text {eco }}$ could not explain the variable responses of $R_{\text {eco }}$ to warming among the three elevations.

Response of

ecosystem

respiration

G. Fu et al.

Title Page

Abstract

Introduction

Conclusions

References

Tables

Figures

14

$\rightarrow 1$

4

Back

Close

Full Screen / Esc

Printer-friendly Version

Interactive Discussion 
There were similar dominant species at the three alpine meadow sites (Table 1), and there were no significant difference in species richness among the three sites (data not shown). Therefore, species change among the three sites could be not the most important factor controlling the different responses of $R_{\text {eco }}$ to warming in this study.

5 In our study, experimental warming had fractional effects on SOC, MBC, DOC and $B G B$ for the three sites and AGB for the two higher elevations, although SOC, MBC, DOC, BGB and AGB at elevation $4693 \mathrm{~m}$ were larger compared to elevation $4513 \mathrm{~m}$ and $4313 \mathrm{~m}$. Therefore, soil organic carbon pools and plant biomass could be also not the dominant factor controlling the different warming effects on $R_{\text {eco }}$, at least in the o short-term.

The relative contribution of water availability to seasonal variation of $R_{\text {eco }}$ at the two lower elevations was larger than that of temperature for the NW + NCL treatment, whereas it showed the quite the contrary result at elevation $4693 \mathrm{~m}$ (Table 4). In addition, precipitation increased with increasing elevation, while temperature increased with decreasing elevation (Table 1). These findings implied that seasonal variation of $R_{\text {eco }}$ was mainly controlled by water availability for the two relative warmer and drier sites under the untreated conditions, whereas the seasonal variation was mainly controlled by temperature for the one relative colder and wetter site. That is, the main control for the seasonal variation of $R_{\text {eco }}$ was dependent on site-specific environmental temperature and water availability conditions.

The net effect of experimental warming on $R_{\text {eco }}$ was determined by relative strengths of experimental warming-induced positive effect by enhancing temperature and negative effect by reducing water availability (Wu et al., 2011a; Liu et al., 2009). In our study, the positive effect was larger than the negative effect for elevation $4693 \mathrm{~m}$, while the positive and negative effects had insignificant differences for elevation $4513 \mathrm{~m}$ and $4313 \mathrm{~m}$.

Inconsistent with our hypothesis, our findings indicated that $R_{\text {eco }}$ did not always have higher temperature sensitivity in colder environments (Kirschbaum, 1995; Wu et al., 2011a). Both temperature and water availability can affect the temperature sensitivity
BGD

10, 13015-13047, 2013

Response of

ecosystem

respiration

G. Fu et al.

Title Page

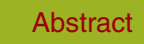

Introduction

Conclusions

Tables

References

Figures

14

$\rightarrow$ I

4

Back

Close

\section{Full Screen / Esc}

Printer-friendly Version

Interactive Discussion 
of $R_{\text {eco }}$ (Lin et al., 2011; Wen et al., 2006) and it is hard to distinguish their effects (Xu and Qi, 2001). Since SOC, MBC, DOC, BGB and AGB had no significant responses to experimental warming, experimental warming-induced significant declines in $Q_{10}$ at the two higher elevations could be mainly attributed to experimental warming-induced 5 increment in temperature and decrement in soil water content (Lin et al., 2011; Zhou et al., 2006), at least in the short-term. These findings suggested that temperature sensitivity of $R_{\text {eco }}$ could be also dependent on environmental temperature and water availability conditions.

In general, the variable experimental warming effects on $R_{\text {eco }}$ were mainly dependent 10 on environmental temperature and water availability conditions.

We observed a similar interannual variation for the responses of growing-season average $R_{\text {eco }}$ to experimental warming along the elevation gradient. The decreased magnitude of $R_{\text {eco }}$ caused by experimental warming at elevation $4313 \mathrm{~m}$ and $4513 \mathrm{~m}$ decreased with year, whereas the increased magnitude of $R_{\text {eco }}$ at elevation $4693 \mathrm{~m}$ increased with year. This finding implied that warming probably had a lagging effect on $R_{\text {eco }}$, which in line with previous studies (Luo et al., 2001; Wan et al., 2005; Fu et al., 2012b).

\subsection{Clipping effect}

Many studies showed that clipping decreased $R_{\text {eco }}$ and soil respiration (Shahzad et al., 20 2012; Bahn et al., 2008; Wan and Luo, 2003), whereas some studies found that clipping had little effect on soil respiration (Zhou et al., 2006). The different responses of soil respiration to clipping may be dependent on clipping intensity and frequency (Allaire et al., 2008). Clipping can decrease soil respiration by weakening assimilation supply from photosynthesis (Bahn et al., 2008; Wan and Luo, 2003) and slowing transloca-
BGD

10, 13015-13047, 2013

Response of

ecosystem

respiration

G. Fu et al.

Title Page

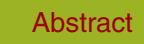

Introduction

Conclusions

Tables

References

Figures

14

$\rightarrow 1$

4

Back

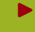

Close

\section{Full Screen / Esc}

Printer-friendly Version

Interactive Discussion may reduce canopy respiration by decreasing aboveground biomass (Shahzad et al., 2012) and microbial respiration by decreasing microbial biomass (Zhang et al., 2005). In our study, we found that $R_{\text {eco }}$ increased significantly with increasing MBC, DOC, BGB 13028 
(Fig. 4b-d) and APB (Fig. 5a). Meanwhile, clipping significantly reduced APB (Fig. 3), but had little effects on MBC, DOC and BGB (Fig. 2). Therefore, consistent with our hypothesis, clipping-induced consistent declines in seasonal average $R_{\text {eco }}$ at the three alpine meadow sites may be mainly due to the removal of aboveground biomass.

\section{$5 \quad$ 4.3 Water availability}

Recent studies have indicated that water availability plays a predominant role in regulating the response of ecosystem carbon flux to climate change in temperate grasslands (Liu et al., 2009; Niu et al., 2008), wet sedge Tundra (Huemmrich et al., 2010) and tallgrass prairie (Xu et al., 2012). Similarly, we also found that SWC was more important 10 than $T_{\mathrm{S}}$ and $T_{\mathrm{a}}$ in regulating the seasonal variation of $R_{\mathrm{eco}}$ and that SWC regulated the response of $R_{\text {eco }}$ to warming for the alpine meadow (Table 4). This phenomenon could be accounted by the following speculations. Firstly, the effect of photosynthetic substrate supply on soil respiration increased with increasing water availability (Yan et al., 2011). The seasonal variation of primary production was regulated by SWC (Fu et al., 2012a). $R_{\text {eco }}$ increased significantly with increasing ANPP and APB (Fig. 5). Meanwhile, ANPP and APB increased with increasing SWC (Fig. 6). Secondly, SOC and its density both increased significantly with increasing SWC (Yang et al., 2008; Liu et al., 2012; Baumann et al., 2009). Similarly, we found that SOC was positively correlated with $R_{\text {eco }}$ and SWC (Figs. 4a and 7a). Thirdly, microbial biomass responded quickly to change in SWC (Skopp et al., 1990). The response of MBC to elevated temperature and the seasonal variation of MBC were regulated by SWC (Liu et al., 2009; Fu et al., $2012 \mathrm{~b}$ ). The positive relationships between $R_{\text {eco }}, \mathrm{MBC}$ and SWC were found (Figs. 4b and $7 \mathrm{~b}$ ). Fourthly, SWC regulated the response of DOC to warming (Christ and David, 1996) and DOC was positively related to $R_{\text {eco }}$ and SWC (Figs. 4c and 7c). Therefore, experimental warming-induced soil drying may suppress vegetation production, SOC, MBC and DOC, which in turn can suppress $R_{\text {eco }}$ (Wu et al., 2011b; Liu et al., 2009; De Boeck et al., 2007). This supported our hypothesis that soil water content can regulate the warming effect on $R_{\text {eco }}$.

BGD

10, 13015-13047, 2013

Response of

ecosystem

respiration

G. Fu et al.
Title Page

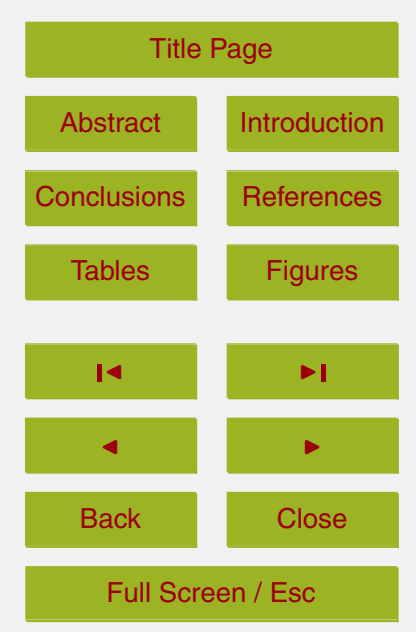

Introduction

Conclusions

References

Tables

Figures

14

$\rightarrow 1$

4

Back

Close

Full Screen / Esc

Printer-friendly Version

Interactive Discussion $\rightarrow$

.




\section{Conclusions}

In summary, we found that the seasonal variations of $R_{\text {eco }}$ were mainly correlated with soil water content in comparison with air and soil temperatures in the alpine meadow of Tibet. Experimental warming significantly increased seasonal average $R_{\mathrm{eco}}$ in one 5 of the three alpine meadow sites (i.e. elevation $4693 \mathrm{~m}$ ), whereas the decreased $R_{\text {eco }}$ caused by experimental warming was not obvious for the alpine meadow at elevation $4313 \mathrm{~m}$ and $4513 \mathrm{~m}$, this different responses could be mainly attributed to different temperature and water availability conditions among the three sites. This finding suggested that the future studies should consider the different responses of $R_{\text {eco }}$ to warm10 ing among the alpine meadow on the Tibetan Plateau. Soil water content regulated the response of $R_{\text {eco }}$ to warming by modulating soil carbon, root biomass and aboveground net primary production. Clipping consistently reduced seasonal average $R_{\text {eco }}$ at the three alpine meadow sites, probably caused by reduced aboveground biomass. Additionally, obvious interactive effect between experimental warming and clipping on $15 R_{\text {eco }}$ was found at elevation $4693 \mathrm{~m}$ in 2010 . These results suggested that clipping may dampen experimental warming-induced positive effect on $R_{\text {eco }}$ in the alpine meadow on the Tibetan Plateau.

Acknowledgements. This work was funded by the National Natural Science Foundation of China (No. 41171084), Innovation Project of the Institute of Geographic Sciences and Natural

20 Resources Research, Chinese Academy of Sciences (No. 2012ZD005), National Science and Technology Plan Project of China (No. 2011BAC09B03) and National Basic Research Program of China (Nos. 2010CB951704, 2010CB833502).

\section{References}

Allaire, S. E., Dufour-L'Arrivee, C., Lafond, J. A., Lalancette, R., and Brodeur, J.: Carbon dioxide
BGD

10, 13015-13047, 2013

Response of

ecosystem

respiration

G. Fu et al.

Title Page

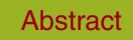

Introduction

Conclusions

References

Tables

Figures

14

$\rightarrow$

4

Back

Close

Full Screen / Esc

Printer-friendly Version

Interactive Discussion 
Bahn, M., Rodeghiero, M., Anderson-Dunn, M., Dore, S., Gimeno, C., Drosler, M., Williams, M., Ammann, C., Berninger, F., Flechard, C., Jones, S., Balzarolo, M., Kumar, S., Newesely, C., Priwitzer, T., Raschi, A., Siegwolf, R., Susiluoto, S., Tenhunen, J., Wohlfahrt, G., and Cernusca, A.: Soil respiration in European grasslands in relation to climate and assimilate sup-

5 ply, Ecosystems, 11, 1352-1367, doi:10.1007/s10021-008-9198-0, 2008.

Baumann, F., He, J. S., Schmidt, K., Kuhn, P., and Scholten, T.: Pedogenesis, permafrost, and soil moisture as controlling factors for soil nitrogen and carbon contents across the Tibetan Plateau, Global Change Biol., 15, 3001-3017, doi:10.1111/j.1365-2486.2009.01953.x, 2009.

10 Bremer, D. J., Ham, J. M., Owensby, C. E., and Knapp, A. K.: Responses of soil respiration to clipping and grazing in a tallgrass prairie, J. Environ. Qual., 27, 1539-1548, 1998.

Cao, G. M., Tang, Y. H., Mo, W. H., Wang, Y. A., Li, Y. N., and Zhao, X. Q.: Grazing intensity alters soil respiration in an alpine meadow on the Tibetan plateau, Soil Biol. Biochem., 36, 237-243, doi:10.1016/j.soilbio.2003.09.010, 2004.

Cheng, X. L., Luo, Y. Q., Su, B., Zhou, X. H., Niu, S. L., Sherry, R., Weng, E. S., and Zhang, Q. F.: Experimental warming and clipping altered litter carbon and nitrogen dynamics in a tallgrass prairie, Agr. Ecosyst. Environ., 138, 206-213, doi:10.1016/j.agee.2010.04.019, 2010.

Christ, M. J. and David, M. B.: Temperature and moisture effects on the production of dissolved organic carbon in a Spodosol, Soil Biol. Biochem., 28, 1191-1199, doi:10.1016/00380717(96)00120-4, 1996.

De Boeck, H. J., Lemmens, C., Vicca, S., Van den Berge, J., Van Dongen, S., Janssens, I. A., Ceulemans, R., and Nijs, I.: How do climate warming and species richness affect $\mathrm{CO}_{2}$ fluxes in experimental grasslands?, New Phytol., 175, 512-522, doi:10.1111/j.14698137.2007.02122.x, 2007.

Fu, G., Shen, Z., Zhang, X., Shi, P., He, Y., Zhang, Y., Sun, W., Wu, J., Zhou, Y., and Pan, X.: Calibration of MODIS-based gross primary production over an alpine meadow on the Tibetan Plateau, Can. J. Remote Sens., 38, 157-168, doi:10.5589/m12-023, 2012a.

Fu, G., Shen, Z., Zhang, X., and Zhou, Y.: Response of soil microbial biomass to short-term experimental warming in alpine meadow on the Tibetan Plateau, Appl. Soil Ecol., 61, 158160, doi:10.1016/j.apsoil.2012.05.002, 2012b.

Response of

ecosystem

respiration

G. Fu et al.

Title Page

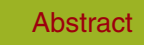

Conclusions

Tables

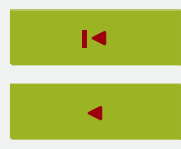

Back

Full Screen / Esc

Printer-friendly Version

Interactive Discussion 
Fu, G., Shen, Z., Zhang, X., Zhou, Y., and Zhang, Y.: Response of microbial biomass to grazing in an alpine meadow along an elevation gradient on the Tibetan Plateau, Eur. J. Soil Biol., 52, 27-29, doi:10.1016/j.ejsobi.2012.05.004, 2012c.

Grogan, P., Illeris, L., Michelsen, A., and Jonasson, S.: Respiration of recently-fixed plant carbon dominates mid-winter ecosystem $\mathrm{CO}_{2}$ production in sub-arctic heath tundra, Climatic Change, 50, 129-142, doi:10.1023/a:1010610131277, 2001.

Hobbie, S. E. and Chapin, F. S.: Response of tundra plant biomass, aboveground production, nitrogen, and $\mathrm{CO}_{2}$ flux to experimental warming, Ecology, 79, 1526-1544, doi:10.1890/00129658(1998)079[1526:trotpb]2.0.co;2, 1998.

10 Huemmrich, K. F., Kinoshita, G., Gamon, J. A., Houston, S., Kwon, H., and Oechel, W. C.: Tundra carbon balance under varying temperature and moisture regimes, J. Geophys. Res.Biogeo., 115, G00I02, doi:10.1029/2009JG001237, 2010.

Illeris, L., Konig, S. M., Grogan, P., Jonasson, S., Michelsen, A., and Ro-Poulsen, H.: Growing-season carbon dioxide flux in a dry subarctic heath: responses to longterm manipulations, Arct. Antarct. Alp. Res., 36, 456-463, doi:10.1657/15230430(2004)036[0456:GCDFIA]2.0.CO;2 , 2004.

IPCC: Climate Change 2007: the Physical Science Basis, Working Group I contribution to the IPCC Fourth Assessment Report, 2007.

Jones, D. L. and Willett, V. B.: Experimental evaluation of methods to quantify dissolved organic nitrogen (DON) and dissolved organic carbon (DOC) in soil, Soil Biol. Biochem., 38, 991999, doi:10.1016/j.soilbio.2005.08.012, 2006.

Kirschbaum, M. U. F.: The temperature dependence of soil organic matter decomposition, and the effect of global warming on soil organic C storage, Soil Biol. Biochem., 27, 753-760, doi:10.1016/0038-0717(94)00242-s, 1995.

Klein, J. A., Harte, J., and Zhao, X. Q.: Experimental warming, not grazing, decreases rangeland quality on the Tibetan Plateau, Ecol. Appl., 17, 541-557, doi:10.1890/05-0685, 2007.

Li, N., Wang, G. X., Yang, Y., Gao, Y. H., and Liu, G. S.: Plant production, and carbon and nitrogen source pools, are strongly intensified by experimental warming in alpine ecosystems in the Qinghai-Tibet Plateau, Soil Biol. Biochem., 43, 942-953, doi:10.1016/j.soilbio.2011.01.009, 2011.

Lin, X. W., Zhang, Z. H., Wang, S. P., Hu, Y. G., Xu, G. P., Luo, C. Y., Chang, X. F., Duan, J. C., Lin, Q. Y., Xu, B., Wang, Y. F., Zhao, X. Q., and Xie, Z. B.: Response of ecosystem respiration

Response of

ecosystem

respiration

G. Fu et al.

Title Page

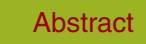

Introduction

Conclusions

References

Tables

Figures

14

$\rightarrow$

4

Back

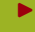

Close

Full Screen / Esc

Printer-friendly Version

Interactive Discussion 
to warming and grazing during the growing seasons in the alpine meadow on the Tibetan plateau, Agr. Forest Meteorol., 151, 792-802, doi:10.1016/j.agrformet.2011.01.009, 2011.

Liu, W. J., Chen, S. Y., Qin, X., Baumann, F., Scholten, T., Zhou, Z. Y., Sun, W. J., Zhang, T. Z., Ren, J. W., and Qin, D. H.: Storage, patterns, and control of soil organic carbon and nitrogen 5 in the northeastern margin of the Qinghai-Tibetan Plateau, Environ. Res. Lett., 7, 035401, doi:10.1088/1748-9326/7/3/035401, 2012.

Liu, W. X., Zhang, Z., and Wan, S. Q.: Predominant role of water in regulating soil and microbial respiration and their responses to climate change in a semiarid grassland, Global Change Biol., 15, 184-195, doi:10.1111/j.1365-2486.2008.01728.x, 2009.

Luo, Y. Q., Wan, S. Q., Hui, D. F., and Wallace, L. L.: Acclimatization of soil respiration to warming in a tall grass prairie, Nature, 413, 622-625, doi:10.1038/35098065, 2001.

Marion, G. M., Henry, G. H. R., Freckman, D. W., Johnstone, J., Jones, G., Jones, M. H., Levesque, E., Molau, U., Molgaard, P., Parsons, A. N., Svoboda, J., and Virginia, R. A.: Opentop designs for manipulating field temperature in high-latitude ecosystems, Global Change

Miehe, G., Mlehe, S., Kaiser, K., Liu, J. Q., and Zhao, X. Q.: Status and dynamics of Kobresia pygmaea ecosystem on the Tibetan plateau, Ambio, 37, 272-279, doi:10.1579/00447447(2008)37[272:SADOTK]2.0.CO;2, 2008.

Miehe, G., Bach, K., Miehe, S., Kluge, J., Yang, Y. P., La, D., Co, S., and Wesche, K.: 20 Alpine steppe plant communities of the Tibetan highlands, Appl. Veg. Sci., 14, 547-560, doi:10.1111/j.1654-109X.2011.01147.x, 2011.

$\mathrm{Ni}$, J.: Carbon storage in grasslands of China, J. Arid Environ., 50, 205-218, doi:10.1006/jare.2001.0902, 2002.

Niu, S. L., Wu, M. Y., Han, Y., Xia, J. Y., Li, L. H., and Wan, S. Q.: Water-mediated responses of ecosystem carbon fluxes to climatic change in a temperate steppe, New Phytol., 177, 209219, doi:10.1111/j.1469-8137.2007.02237.x, 2008.

Oberbauer, S. F., Tweedie, C. E., Welker, J. M., Fahnestock, J. T., Henry, G. H. R., Webber, P. J., Hollister, R. D., Walker, M. D., Kuchy, A., Elmore, E., and Starr, G.: Tundra $\mathrm{CO}_{2}$ fluxes in response to experimental warming across latitudinal and moisture gradients, Ecol. Monogr., $30 \quad$ 77, 221-238, doi:10.1890/06-0649, 2007.

Rui, Y. C., Wang, S. P., Xu, Z. H., Wang, Y. F., Chen, C. R., Zhou, X. Q., Kang, X. M., Lu, S. B., $\mathrm{Hu}$, Y. G., Lin, Q. Y., and Luo, C. Y.: Warming and grazing affect soil labile carbon and
BGD

10, 13015-13047, 2013

Response of

ecosystem

respiration

G. Fu et al.

Title Page

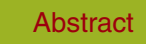

Introduction

Conclusions

References

Tables

Figures

14

$\rightarrow$ I

4

Back

Close

Full Screen / Esc

Printer-friendly Version

Interactive Discussion 
nitrogen pools differently in an alpine meadow of the Qinghai-Tibet Plateau in China, J. Soil Sediment., 11, 903-914, doi:10.1007/s11368-011-0388-6, 2011.

Shahzad, T., Chenu, C., Repincay, C., Mougin, C., Ollier, J. L., and Fontaine, S.: Plant clipping decelerates the mineralization of recalcitrant soil organic matter under multiple grassland species, Soil Biol. Biochem., 51, 73-80, doi:10.1016/j.soilbio.2012.04.014, 2012.

Shi, P. L., Sun, X. M., Xu, L. L., Zhang, X. Z., He, Y. T., Zhang, D. Q., and Yu, G. R.: Net ecosystem $\mathrm{CO}_{2}$ exchange and controlling factors in a steppe - Kobresia meadow on the Tibetan Plateau, Sci. China Ser. D, 49, 207-218, doi:10.1007/s11430-006-8207-4, 2006.

Skopp, J., Jawson, M. D., and Doran, J. W.: Steady-state aerobic microbial activity as a function of soil water content, Soil Sci. Soc. Am. J., 54, 1619-1625, 1990.

Sun, J., Cheng, G. W., and Li, W. P.: Meta-analysis of relationships between environmental factors and aboveground biomass in the alpine grassland on the Tibetan Plateau, Biogeosciences, 10, 1707-1715, doi:10.5194/bg-10-1707-2013, 2013.

Vance, E. D., Brookes, P. C., and Jenkinson, D. S.: An extraction method for measuring soil 15 microbial biomass C, Soil Biol. Biochem., 19, 703-707, doi:10.1016/0038-0717(87)90052-6, 1987.

Walkley, A. and Black, I. A.: An examination of the Degtjareff method for determining soil organic matter, and a proposed modification of the chromic acid titration method, Soil Sci., 37, 2938, doi:10.1097/00010694-193401000-00003, 1934.

20

Wan, S. Q. and Luo, Y. Q.: Substrate regulation of soil respiration in a tallgrass prairie: results of a clipping and shading experiment, Global Biogeochem. Cy., 17, 1054, doi:10.1029/2002GB001971, 2003.

Wan, S. Q., Hui, D. F., Wallace, L., and Luo, Y. Q.: Direct and indirect effects of experimental warming on ecosystem carbon processes in a tallgrass prairie, Global Biogeochem. Cy., 19, GB2014, doi:10.1029/2004gb002315, 2005.

Wang, Z., Luo, T. X., Li, R. C., Tang, Y. H., and Du, M. Y.: Causes for the unimodal pattern of biomass and productivity in alpine grasslands along a large altitudinal gradient in semi-arid regions, J. Veg. Sci., 24, 189-201, doi:10.1111/j.1654-1103.2012.01442.x, 2013.

Welker, J. M., Brown, K. B., and Fahnestock, J. T.: $\mathrm{CO}_{2}$ flux in Arctic and alpine dry tundra: comparative field responses under ambient and experimentally warmed conditions, Arct. Antarct. Alp. Res., 31, 272-277, doi:10.2307/1552257, 1999.

Welker, J. M., Fahnestock, J. T., Henry, G. H. R., O'Dea, K. W., and Chimner, R. A.: $\mathrm{CO}_{2}$ exchange in three Canadian High Arctic ecosystems: response to long-term experimen-
BGD

10, 13015-13047, 2013

Response of

ecosystem

respiration

G. Fu et al.

Title Page

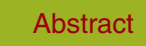

Introduction

Conclusions

References

Tables

Figures

14

$\rightarrow$ I

4

Back

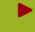

Close

Full Screen / Esc

Printer-friendly Version

Interactive Discussion 
tal warming, Global Change Biol., 10, 1981-1995, doi:10.1111/j.1365-2486.2004.00857.x, 2004.

Wen, X. F., Yu, G. R., Sun, X. M., Li, Q. K., Liu, Y. F., Zhang, L. M., Ren, C. Y., Fu, Y. L., and $\mathrm{Li}, \mathrm{Z}$. Q.: Soil moisture effect on the temperature dependence of ecosystem respiration in 5 a subtropical Pinus plantation of southeastern China, Agr. Forest Meteorol., 137, 166-175, doi:10.1016/j.agrformet.2006.02.005, 2006.

Wohlfahrt, G., Anderson-Dunn, M., Bahn, M., Balzarolo, M., Berninger, F., Campbell, C., Carrara, A., Cescatti, A., Christensen, T., Dore, S., Eugster, W., Friborg, T., Furger, M., Gianelle, D., Gimeno, C., Hargreaves, K., Hari, P., Haslwanter, A., Johansson, T., Marcolla, B., Milford, C., Nagy, Z., Nemitz, E., Rogiers, N., Sanz, M. J., Siegwolf, R. T. W., Susiluoto, S., Sutton, M., Tuba, Z., Ugolini, F., Valentini, R., Zorer, R., and Cernusca, A.: Biotic, abiotic, and management controls on the net ecosystem $\mathrm{CO}_{2}$ exchange of European mountain grassland ecosystems, Ecosystems, 11, 1338-1351, doi:10.1007/s10021-008-9196-2, 2008.

Wu, Z. T., Dijkstra, P., Koch, G. W., Penuelas, J., and Hungate, B. A.: Responses of terres15 trial ecosystems to temperature and precipitation change: a meta-analysis of experimental manipulation, Global Change Biol., 17, 927-942, doi:10.1111/j.1365-2486.2010.02302.x, $2011 a$.

Wu, Z. T., Koch, G. W., Dijkstra, P., Bowker, M. A., and Hungate, B. A.: Responses of ecosystem carbon cycling to climate change treatments along an elevation gradient, Ecosystems, 14, $20 \quad$ 1066-1080, doi:10.1007/s10021-011-9464-4, 2011b.

Xia, J. Y., Niu, S. L., and Wan, S. Q.: Response of ecosystem carbon exchange to warming and nitrogen addition during two hydrologically contrasting growing seasons in a temperate steppe, Global Change Biol., 15, 1544-1556, doi:10.1111/j.1365-2486.2008.01807.x, 2009.

Xie, H., Ye, J. S., Liu, X. M., and E, C. Y.: Warming and drying trends on the Tibetan Plateau 25 (1971-2005), Theor. Appl. Climatol., 101, 241-253, doi:10.1007/s00704-009-0215-9, 2010.

$\mathrm{Xu}, \mathrm{M}$. and Qi, Y.: Spatial and seasonal variations of $\mathrm{Q}_{10}$ determined by soil respiration measurements at a Sierra Nevadan forest, Global Biogeochem. Cy., 15, 687-696, doi:10.1029/2000gb001365, 2001.

Xu, X., Niu, S. L., Sherry, R. A., Zhou, X. H., Zhou, J. Z., and Luo, Y. Q.: Interannual vari30 ability in responses of belowground net primary productivity (NPP) and NPP partitioning to long-term warming and clipping in a tallgrass prairie, Global Change Biol., 18, 1648-1656, doi:10.1111/j.1365-2486.2012.02651.x, 2012.

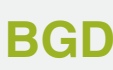

$10,13015-13047,2013$

Response of

ecosystem

respiration

G. Fu et al.

Title Page

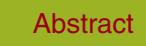

Introduction

Conclusions

References

Tables

Figures

14

$>$ I

4

Back

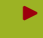

Close

Full Screen / Esc

Printer-friendly Version

Interactive Discussion 
Yan, L. M., Chen, S. P., Huang, J. H., and Lin, G. H.: Water regulated effects of photosynthetic substrate supply on soil respiration in a semiarid steppe, Global Change Biol., 17, 19902001, doi:10.1111/j.1365-2486.2010.02365.x, 2011.

Yang, Y. H., Fang, J. Y., Tang, Y. H., Ji, C. J., Zheng, C. Y., He, J. S., and Zhu, B. A.: Storage, 5 patterns and controls of soil organic carbon in the Tibetan grasslands, Global Change Biol., 14, 1592-1599, doi:10.1111/j.1365-2486.2008.01591.x, 2008.

Yu, C. Q., Zhang, Y. J., Claus, H., Zeng, R., Zhang, X. Z., and Wang, J. S.: Ecological and environmental issues faced by a developing Tibet, Environ. Sci. Technol., 46, 1979-1980, doi:10.1021/es2047188, 2012.

10 Zhang, L., Guo, H. D., Ji, L., Lei, L. P., Wang, C. Z., Yan, D. M., Li, B., and Li, J.: Vegetation greenness trend (2000 to 2009) and the climate controls in the Qinghai-Tibetan Plateau, J. Appl. Remote Sens., 7, 073572, doi:10.1117/1.jrs.7.073572, 2013.

Zhang, W., Parker, K. M., Luo, Y., Wan, S., Wallace, L. L., and Hu, S.: Soil microbial responses to experimental warming and clipping in a tallgrass prairie, Global Change Biol., 11, 266277, doi:10.1111/j.1365-2486.2005.00902.x, 2005.

Zhou, X. H., Sherry, R. A., An, Y., Wallace, L. L., and Luo, Y. Q.: Main and interactive effects of warming, clipping, and doubled precipitation on soil $\mathrm{CO}_{2}$ efflux in a grassland ecosystem, Global Biogeochem. Cy., 20, GB1003, doi:10.1029./2005GB002526, 2006.

Zhuang, Q., He, J., Lu, Y., Ji, L., Xiao, J., and Luo, T.: Carbon dynamics of terrestrial ecosystems on the Tibetan Plateau during the 20th century: an analysis with a processbased biogeochemical model, Global Ecol. Biogeogr., 19, 649-662, doi:10.1111/j.14668238.2010.00559.x, 2010.

Zimmermann, M., Meir, P., Bird, M. I., Malhi, Y., and Ccahuana, A. J. Q.: Climate dependence of heterotrophic soil respiration from a soil-translocation experiment along a $3000 \mathrm{~m}$ tropical forest altitudinal gradient, Eur. J. Soil Sci., 60, 895-906, doi:10.1111/j.1365-2389.2009.01175.x, 2009.

Response of

ecosystem

respiration

G. Fu et al.

Title Page

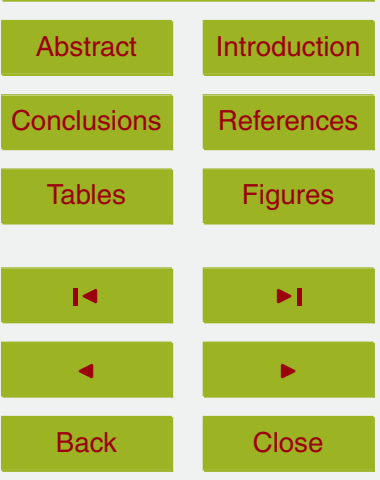

Full Screen / Esc

Printer-friendly Version

Interactive Discussion 
Table 1. Sites description.

BGD

10, 13015-13047, 2013

Response of

ecosystem

respiration

G. Fu et al.

\begin{tabular}{|c|c|c|c|}
\hline Site & Site 1 & Site 2 & Site 3 \\
\hline Location & $30^{\circ} 30^{\prime} \mathrm{N} 91^{\circ} 04^{\prime} \mathrm{E}$ & $30^{\circ} 31^{\prime} \mathrm{N} 91^{\circ} 04^{\prime} \mathrm{E}$ & $30^{\circ} 32^{\prime} \mathrm{N} 91^{\circ} 03^{\prime} \mathrm{E}$ \\
\hline Elevation (m) & 4313 & 4513 & 4693 \\
\hline Dominant species & $\begin{array}{l}\text { Stipa capillacea, } \\
\text { Carex montis-everestii, } \\
\text { Kobresia pygmaea }\end{array}$ & $\begin{array}{l}\text { Stipa capillacea, } \\
\text { Kobresia pygmaea, } \\
\text { Carex montis-everestii }\end{array}$ & Kobresia pygmaea \\
\hline Canopy height $(\mathrm{cm})$ & $<10$ & $<10$ & $<10$ \\
\hline Vegetation coverage (\%) & $<50$ & $<50$ & $>50$ \\
\hline Air temperature $\left({ }^{\circ} \mathrm{C}\right)^{\mathrm{a}}$ & 10.24 & 9.53 & 8.23 \\
\hline Precipitation $(m)^{\mathrm{a}}$ & 255.25 & 282.87 & 341.43 \\
\hline Soil organic carbon $\left(0-30 \mathrm{~cm}, \mathrm{~g} \mathrm{~kg}^{-1}\right)$ & $19.83 \pm 0.36$ & $24.04 \pm 0.34$ & $43.74 \pm 0.60$ \\
\hline Total nitrogen $\left(0-30 \mathrm{~cm}, \mathrm{~g} \mathrm{~kg}^{-1}\right)$ & $2.12 \pm 0.19$ & $2.18 \pm 0.18$ & $3.32 \pm 0.12$ \\
\hline
\end{tabular}

${ }^{a}$ Data were average temperature or total precipitation during the period from June to September.

Interactive Discussion

\section{Full Screen / Esc}

Printer-friendly Version 
Table 2. Repeated-measures analysis of variance for the main and interactive effects of year $(Y)$, elevation $(E)$, experimental warming $(\mathrm{W})$ and clipping $(C L)$ on growing-season average ecosystem respiration $\left(R_{\text {eco }}\right)$ in the alpine meadow along an elevation gradient $(4313-4693 \mathrm{~m})$ $(n=3)$.

\begin{tabular}{lrrr}
\hline Model & $\mathrm{d} f$ & $F$ & $p$ \\
\hline $\mathrm{W}$ & 1,24 & 1.96 & 0.17 \\
$\mathrm{CL}$ & 1,24 & 50.16 & $<0.001$ \\
$\mathrm{E}$ & 2,24 & 29.62 & $<0.001$ \\
$\mathrm{Y}$ & 2,48 & 42.41 & $<0.001$ \\
$\mathrm{~W} \times \mathrm{CL}$ & 1,24 & 0.01 & 0.93 \\
$\mathrm{~W} \times \mathrm{E}$ & 2,24 & 5.50 & $<0.05$ \\
$\mathrm{CL} \times \mathrm{E}$ & 2,24 & 8.10 & $<0.01$ \\
$\mathrm{~W} \times \mathrm{Y}$ & 2,48 & 7.57 & $<0.01$ \\
$\mathrm{CL} \times \mathrm{Y}$ & 2,48 & 5.95 & $<0.01$ \\
$\mathrm{E} \times \mathrm{Y}$ & 4,48 & 2.64 & $<0.05$ \\
$\mathrm{~W} \times \mathrm{CL} \times \mathrm{E}$ & 2,24 & 2.68 & 0.09 \\
$\mathrm{~W} \times \mathrm{CL} \times \mathrm{Y}$ & 2,48 & 0.44 & 0.65 \\
$\mathrm{~W} \times \mathrm{E} \times \mathrm{Y}$ & 4,48 & 0.46 & 0.77 \\
$\mathrm{CL} \times \mathrm{E} \times \mathrm{Y}$ & 4,48 & 1.02 & 0.41 \\
$\mathrm{~W} \times \mathrm{CL} \times \mathrm{E} \times \mathrm{Y}$ & 4,48 & 0.26 & 0.90 \\
\hline
\end{tabular}

Response of

ecosystem

respiration

G. Fu et al.

Title Page

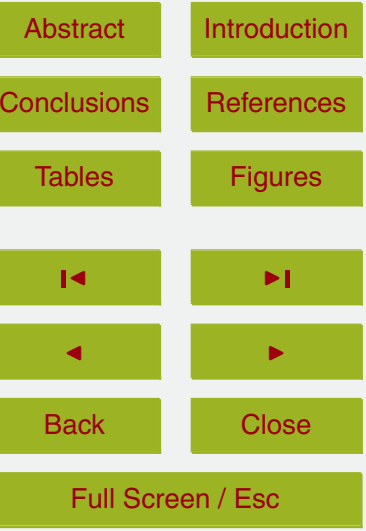

Printer-friendly Version

Interactive Discussion 
Response of

ecosystem

respiration

Table 3. Repeated-measures analysis of variance for the main and their interactive effects of measuring date (D), experimental warming $(W)$ and clipping $(C L)$ on diurnal average ecosystem respiration $\left(R_{\text {eco }}\right)$ in the three alpine meadows at elevation $4313 \mathrm{~m}, 4513 \mathrm{~m}$ and $4693 \mathrm{~m}$ during the growing season (from June to September) in 2010, 2011 and 2012, respectively $(n=3)$.

\begin{tabular}{|c|c|c|c|c|c|c|c|c|c|c|c|c|}
\hline \multirow[t]{2}{*}{ Model } & \multicolumn{4}{|c|}{2010} & \multicolumn{4}{|c|}{2011} & \multicolumn{4}{|c|}{2012} \\
\hline & $\mathrm{d} f$ & 4313 & 4513 & 4693 & $\mathrm{~d} f$ & 4313 & 4513 & 4693 & $\mathrm{~d} f$ & 4313 & 4513 & 4693 \\
\hline W & 1,8 & $5.57^{\mathrm{a}}$ & $12.34^{b}$ & 1.59 & 1,8 & 4.64 & 0.53 & $5.50^{\mathrm{a}}$ & 1,8 & 0.61 & 0.67 & $5.40^{\mathrm{a}}$ \\
\hline$C L$ & 1,8 & 0.02 & $37.11^{c}$ & $47.41^{c}$ & 1,8 & 0.37 & $32.88^{\mathrm{C}}$ & $61.06^{\mathrm{c}}$ & 1,8 & 0.96 & $39.34^{\mathrm{C}}$ & $50.88^{C}$ \\
\hline $\mathrm{D}$ & 7,56 & $22.83^{c}$ & $114.09^{c}$ & $128.78^{c}$ & 6,48 & $61.71^{\mathrm{C}}$ & $97.87^{\mathrm{C}}$ & $60.32^{c}$ & 6,48 & $122.60^{c}$ & $148.85^{c}$ & $45.76^{c}$ \\
\hline $\mathrm{W} \times \mathrm{CL}$ & 1,8 & 0.58 & 0.00 & $5.95^{a}$ & 1,8 & 2.54 & 0.09 & 1.83 & 1,8 & 0.78 & 0.02 & 4.60 \\
\hline$W \times D$ & 7,56 & $7.93^{c}$ & $5.85^{\mathrm{b}}$ & $17.07^{c}$ & 6,48 & $2.54^{a}$ & $7.69^{b}$ & 0.69 & 6,48 & $2.56^{a}$ & $9.09^{b}$ & 1.38 \\
\hline$C L \times D$ & 7,56 & $2.29^{a}$ & $8.65^{c}$ & $2.62^{\mathrm{a}}$ & 6,48 & 1.67 & $8.04^{b}$ & 4.41 & 6,48 & $3.26^{b}$ & $6.52^{b}$ & $4.60^{\mathrm{a}}$ \\
\hline $\mathrm{W} \times \mathrm{CL} \times \mathrm{D}$ & 7,56 & 0.96 & 1.97 & 0.85 & 6,48 & $3.02^{a}$ & 1.71 & 0.51 & 6,48 & 1.48 & $5.28^{a}$ & 0.57 \\
\hline
\end{tabular}

${ }^{a},{ }^{b}$ and ${ }^{c}$ mean significant at $0.05,0.01$ and 0.001 level.

G. Fu et al.

Title Page

Abstract

Introduction

Conclusions

References

Tables

Figures

14

4

Back

Close

Full Screen / Esc

Printer-friendly Version

Interactive Discussion 
Table 4. Stepwise multiple linear regression analyses between diurnal mean ecosystem respiration $\left(R_{\text {eco }}\right)$ and soil temperature at the depth of $5 \mathrm{~cm}\left(T_{\mathrm{s}}\right)$, soil water content at the depth of $10 \mathrm{~cm}(\mathrm{SWC})$ and air temperature at the height of $15 \mathrm{~cm}$ above the ground $\left(T_{\mathrm{a}}\right)$, showing regression coefficient (Coef., mean $\pm \mathrm{SE}$ ), significance probability $(p)$ and coefficient of determination $\left(R^{2}\right)$ change. Natural logarithm transformations were made for $R_{\text {eco }}$ and SWC before regression analysis. Diurnal mean $T_{\mathrm{s}}$, SWC and $T_{\mathrm{a}}$ coincide with diurnal mean $R_{\text {eco. }}$. All the 22 diurnal average data were used.

\begin{tabular}{|c|c|c|c|c|c|c|c|c|c|c|c|c|c|}
\hline \multirow[t]{2}{*}{ Elevation (m) } & \multirow[t]{2}{*}{ Factor } & \multicolumn{3}{|c|}{$\mathrm{NW}+\mathrm{NCL}$} & \multicolumn{3}{|c|}{$\mathrm{W}+\mathrm{NCL}$} & \multicolumn{3}{|c|}{$\mathrm{CL}+\mathrm{NW}$} & \multicolumn{3}{|c|}{$\mathrm{W}+\mathrm{CL}$} \\
\hline & & Coef. & $p$ & $R^{2}$ & Coef. & $p$ & $R^{2}$ & Coef. & $p$ & $R^{2}$ & Coef. & $p$ & $R^{2}$ \\
\hline \multirow[t]{2}{*}{4313} & Constant & $1.86 \pm 0.22$ & $<0.001$ & & $1.76 \pm 0.16$ & $<0.001$ & & $1.76 \pm 0.26$ & $<0.001$ & & $1.65 \pm 0.23$ & $<0.001$ & \\
\hline & SWC & $0.39 \pm 0.11$ & 0.003 & 0.37 & $0.46 \pm 0.07$ & $<0.001$ & 0.72 & $0.42 \pm 0.13$ & 0.004 & 0.34 & $0.34 \pm 0.09$ & 0.001 & 0.45 \\
\hline \multirow[t]{3}{*}{4513} & Constant & $2.18 \pm 0.32$ & $<0.001$ & & $2.54 \pm 0.16$ & $<0.001$ & & $1.21 \pm 0.26$ & $<0.001$ & & $1.90 \pm 0.21$ & $<0.001$ & \\
\hline & SWC & $1.24 \pm 0.17$ & $<0.001$ & 0.67 & $0.82 \pm 0.08$ & $<0.001$ & 0.83 & $\begin{array}{l}0.67 \pm 0.09 \\
0.05 \pm 0.02\end{array}$ & $\begin{array}{r}<0.001 \\
0.026\end{array}$ & $\begin{array}{l}0.66 \\
0.08\end{array}$ & $0.71 \pm 0.10$ & $<0.001$ & 0.71 \\
\hline & & $0.06 \pm 0.02$ & 0.021 & 0.08 & & & & $0.05 \pm 0.02$ & 0.020 & 0.08 & & & \\
\hline \multirow[t]{3}{*}{4693} & Constant & $1.20 \pm 0.23$ & $<0.001$ & & $1.62 \pm 0.27$ & $<0.001$ & & $1.44 \pm 0.26$ & $<0.001$ & & $1.99 \pm 0.23$ & $<0.001$ & \\
\hline & $\begin{array}{l}\text { SWC } \\
T_{\mathrm{a}}\end{array}$ & $0.89 \pm 0.13$ & $<0.001$ & 0.22 & $0.50 \pm 0.09$ & $<0.001$ & 0.51 & $\begin{array}{l}0.69 \pm 0.17 \\
0.06 \pm 0.02\end{array}$ & $\begin{array}{r}0.001 \\
0.01\end{array}$ & $\begin{array}{l}0.24 \\
0.23\end{array}$ & $0.46 \pm 0.11$ & $<0.001$ & 0.47 \\
\hline & $T_{\mathrm{s}}$ & $0.13 \pm 0.02$ & $<0.001$ & 0.49 & $0.06 \pm 0.03$ & 0.018 & 0.13 & & & & & & \\
\hline
\end{tabular}

Response of

ecosystem

respiration

G. Fu et al.

Title Page

Abstract

Introduction

Conclusions

References

Tables

Figures

14

$\rightarrow$

4

Back

Close

\section{Full Screen / Esc}

Printer-friendly Version

Interactive Discussion 


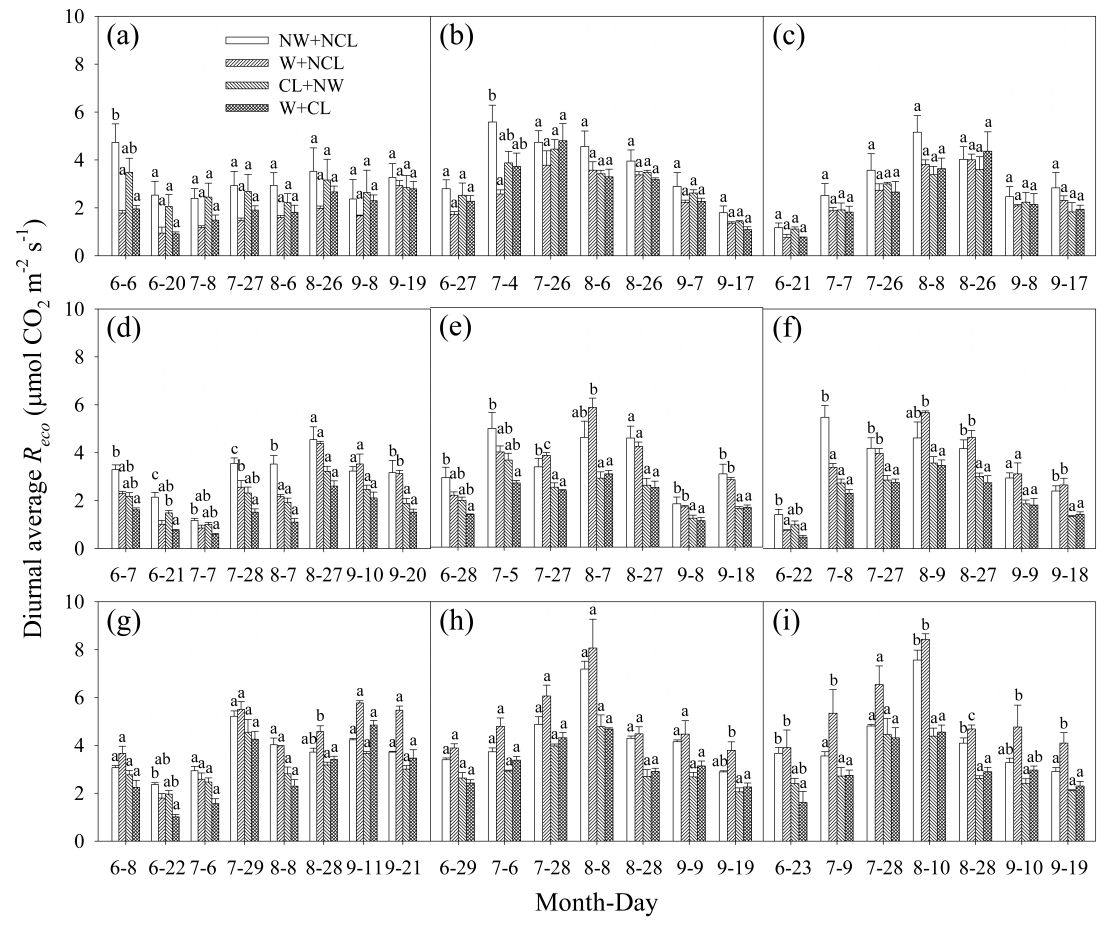

Fig. 1. Diurnal average ecosystem respiration $\left(R_{\text {eco }}, \mu \mathrm{mol} \mathrm{CO}_{2} \mathrm{~m}^{-2} \mathrm{~s}^{-1}\right)$ for the no warming and no clipping (NW $+\mathrm{NCL}$ ), warming and no clipping $(\mathrm{W}+\mathrm{NCL})$, clipping and no warming $(C L+N W)$ and warming plus clipping $(W+C L)$ treatments in the three alpine meadow sites at elevation $4313 \mathrm{~m}(\mathbf{a}, \mathbf{b}, \mathbf{c}), 4513 \mathrm{~m}(\mathbf{d}, \mathbf{e}, \mathbf{f})$ and $4693 \mathrm{~m}(\mathbf{g}, \mathbf{h}, \mathbf{i})$ during the three consecutive growing seasons in 2010 (a, d, g), 2011 (b, e, h) and 2012 (c, f, i), respectively. Error bars represent standard error $(n=3)$. Different letters mean statistical significant at $p<0.05$.

\section{BGD}

10, 13015-13047, 2013

Response of

ecosystem

respiration

G. Fu et al.

Title Page

Abstract Introduction

Conclusions

References

Tables

Figures

14

$>1$

4

Back

Close

\section{Full Screen / Esc}

Printer-friendly Version

Interactive Discussion 


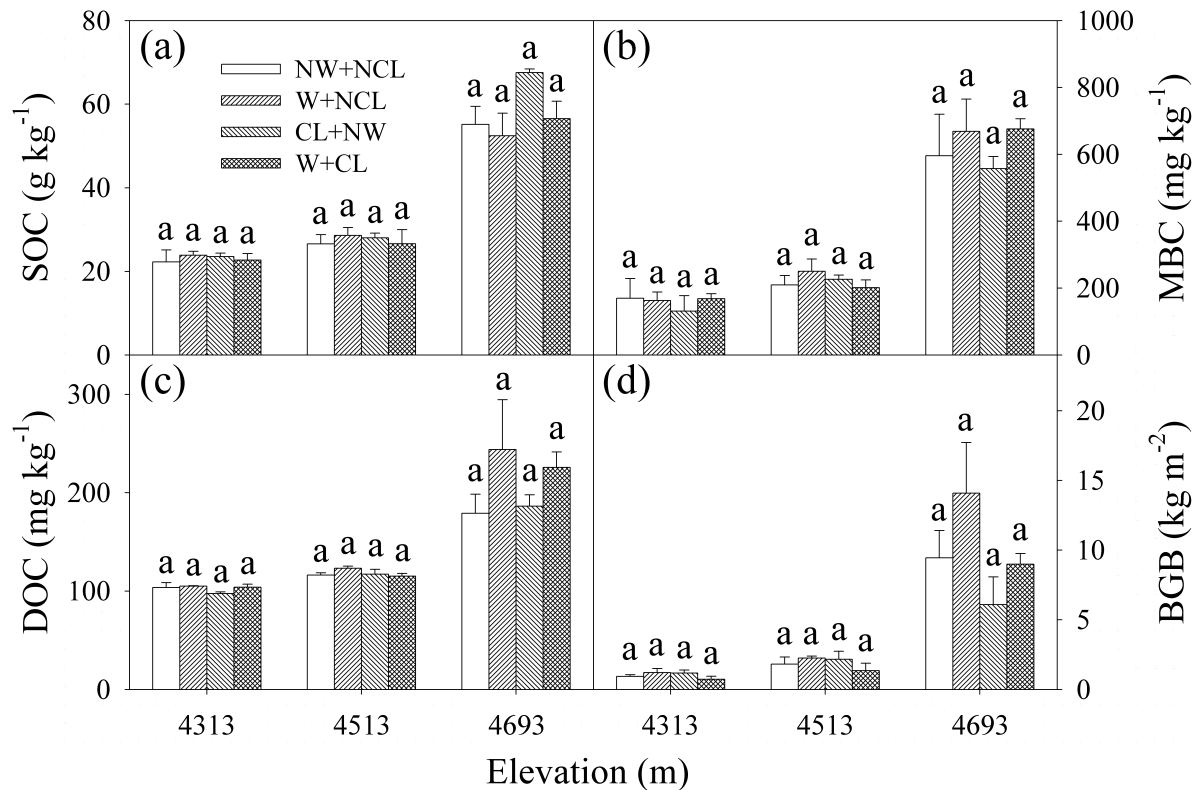

Fig. 2. Topsoil $(0-20 \mathrm{~cm})$ soil organic carbon $\left(\mathrm{SOC}, \mathrm{g} \mathrm{kg}^{-1}\right)$ (a), microbial biomass carbon $\left(\mathrm{MBC}, \mathrm{mg} \mathrm{kg}^{-1}\right)(\mathbf{b})$, dissolved organic carbon (DOC, $\left.\mathrm{mg} \mathrm{kg}^{-1}\right)$ (c) and belowground biomass $\left(B G B, \mathrm{~kg} \mathrm{~m}^{-2}\right.$ ) (d) in the three alpine meadow sites along an elevation gradient (4313-4693 m) in August 2012. Error bars represent standard error $(n=3)$. Different letters mean statistical significant at $p<0.05$.
BGD

10, 13015-13047, 2013

Response of

ecosystem

respiration

G. Fu et al.

\section{Title Page}

Abstract

Introduction

Conclusions

References

Tables

Figures

14

$\rightarrow$

4

Back

Close

\section{Full Screen / Esc}

Printer-friendly Version

Interactive Discussion 


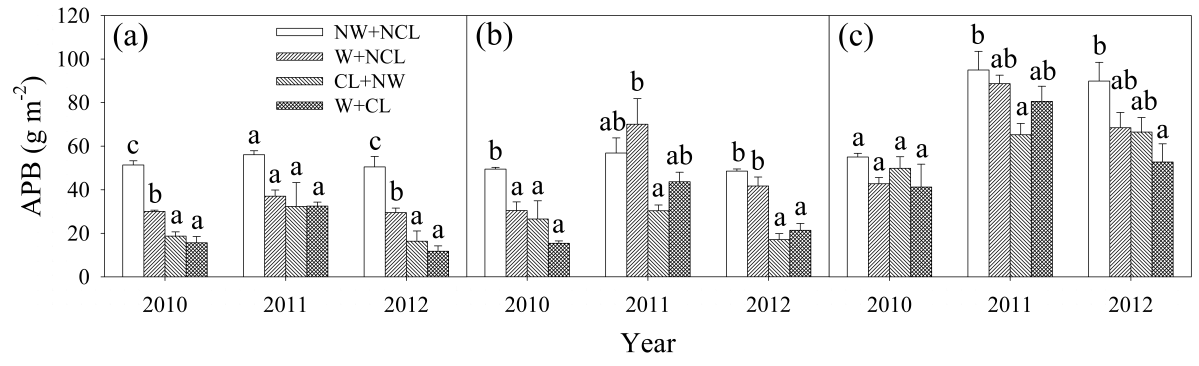

Fig. 3. Aboveground present biomass (APB, $\mathrm{g} \mathrm{m}^{-2}$ ) in the three alpine meadow sites at elevation $4313 \mathrm{~m}$ (a), $4513 \mathrm{~m}$ (b) and $4693 \mathrm{~m}$ (c) in August 2010-2012. Error bars represent standard error $(n=3)$. Different letters mean statistical significant at $p<0.05$.

\section{BGD}

10, 13015-13047, 2013

\section{Response of ecosystem respiration}

\section{G. Fu et al.}

\section{Title Page}

Abstract Introduction

Conclusions References

Tables

Figures

14 $\rightarrow$

4

Back

Close

\section{Full Screen / Esc}

Printer-friendly Version

Interactive Discussion 


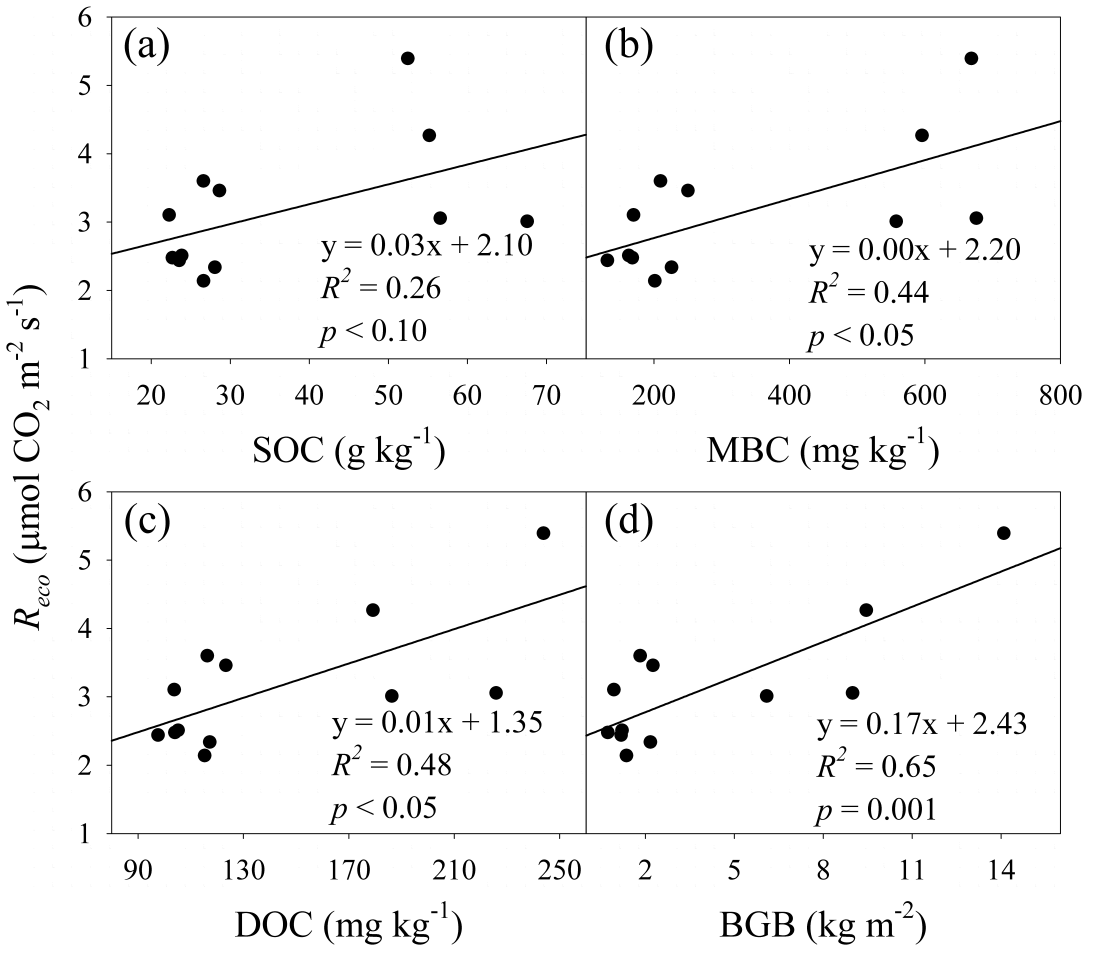

BGD

10, 13015-13047, 2013

Response of

ecosystem

respiration

G. Fu et al.

Title Page

Abstract

Introduction

Conclusions

References

Tables

Figures

14

> I

4

Back

Close

\section{Full Screen / Esc}

Printer-friendly Version

Interactive Discussion 


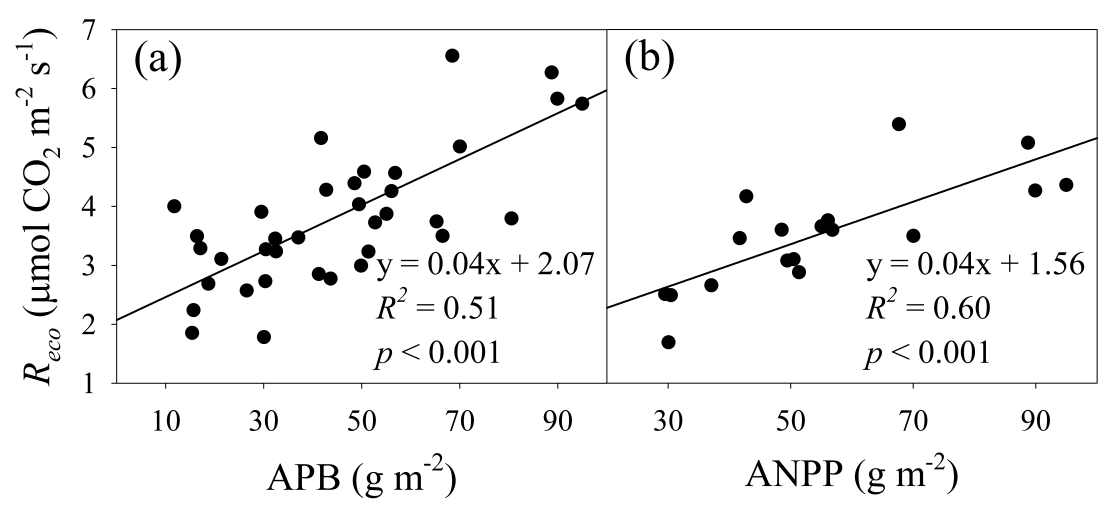

Fig. 5. Relationships between monthly average ecosystem respiration $\left(R_{\mathrm{eco}}, \mu \mathrm{mol} \mathrm{CO}_{2} \mathrm{~m}^{-2} \mathrm{~s}^{-1}\right)$ in August and aboveground present biomass (APB, $\mathrm{g} \mathrm{m}^{-2}$ ) (a); and growing-season average $R_{\text {eco }}$ and aboveground net primary production (ANPP, $\mathrm{g} \mathrm{m}^{-2}$ ) in the unclipped plots (b) in the alpine meadow along an elevation gradient (4313-4693 m).
BGD

10, 13015-13047, 2013

Response of

ecosystem

respiration

G. Fu et al.

Title Page

Abstract

Introduction

Conclusions

References

Tables

Figures

14

$\rightarrow$

4

Back

Close

Full Screen / Esc

Printer-friendly Version

Interactive Discussion 


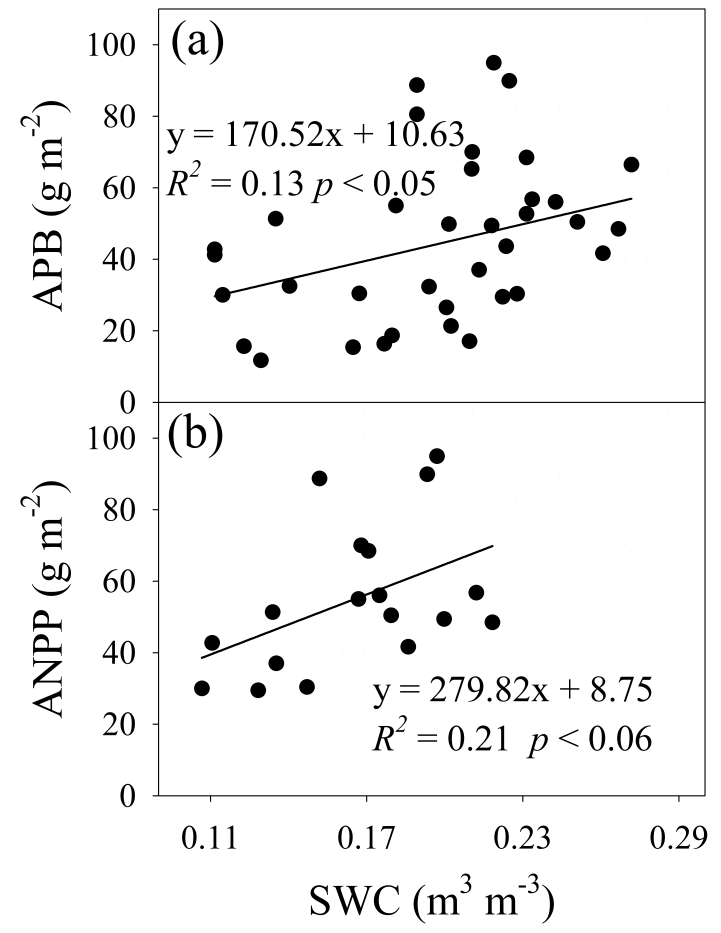

Fig. 6. Relationships between aboveground present biomass (APB, $\mathrm{gm}^{-2}$ ) and monthly average soil water content (SWC, $\mathrm{m}^{3} \mathrm{~m}^{-3}$ ) in August (a) and aboveground net primary production (ANPP, $\mathrm{g} \mathrm{m}^{-2}$ ) in the unclipped plots and growing-season average SWC (b) in the alpine meadow along an elevation gradient (4313-4693 m).
BGD

10, 13015-13047, 2013

Response of

ecosystem

respiration

G. Fu et al.

Title Page

Abstract

Introduction

Conclusions

References

Tables

Figures

14

$>$ I

4

Back

Close

Full Screen / Esc

Printer-friendly Version

Interactive Discussion 


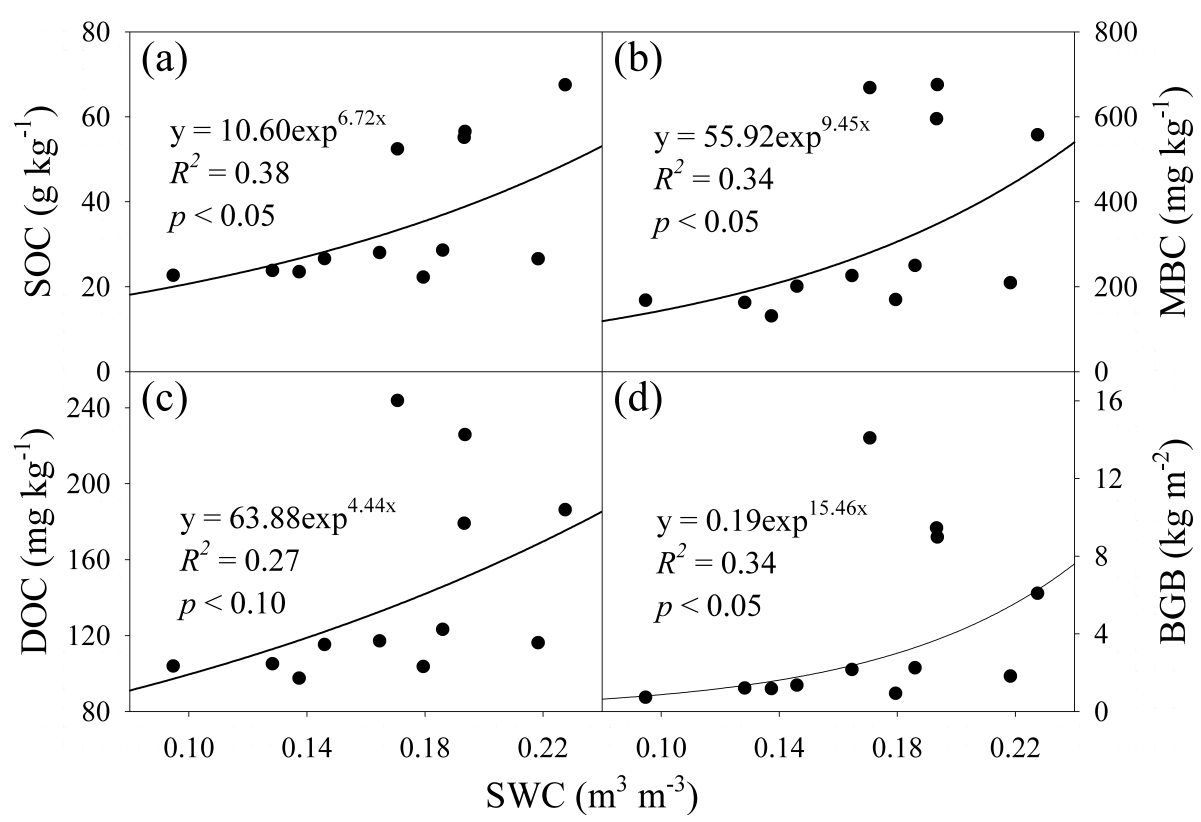

Fig. 7. Relationships between soil organic carbon (SOC, $\left.\mathrm{g} \mathrm{kg}^{-1}\right)$ and growing-season average soil water content $\left(\mathrm{SWC}, \mathrm{m}^{3} \mathrm{~m}^{-3}\right)$ (a); microbial biomass carbon (MBC, $\mathrm{mg} \mathrm{kg}^{-1}$ ) and growingseason average SWC (b); dissolved organic carbon (DOC, $\mathrm{mg} \mathrm{kg}^{-1}$ ) and growing-season average SWC (c) and belowground biomass (BGB, $\mathrm{kg} \mathrm{m}^{-2}$ ) and growing-season average SWC in 2012.
BGD

10, 13015-13047, 2013

Response of

ecosystem

respiration

G. Fu et al.

Title Page

Abstract

Introduction

Conclusions

References

Tables

Figures

14

$>$ I

4

Back

Close

Full Screen / Esc

Printer-friendly Version

Interactive Discussion 